Original Research

\title{
Evaluation of Water Quality and Its Potential Threats Along River Chenab Using Geo Statistical Techniques
}

\author{
Ayesha Siddiqua ${ }^{1 * * *}$, Yumna Sadef ${ }^{1}$, Sheikh Saeed Ahmad², \\ Mujahid Farid ${ }^{3 *}$, Shafaqat Ali ${ }^{4,5 * *}$ \\ ${ }^{1}$ College of Earth and Environmental Sciences, University of the Punjab, Lahore- 54590, Pakistan \\ ${ }^{2}$ Department of Environmental Sciences, Fatima Jinnah Women University, Rawalpindi, Pakistan \\ ${ }^{3}$ Department of Environmental Sciences, University of Gujrat, Hafiz Hayat Campus, Gujrat, 50700, Pakistan \\ ${ }^{4}$ Department of Environmental Sciences and Engineering, Government College University, Faisalabad, 38000, Pakistan \\ ${ }^{5}$ Department of Biological Sciences and Technology, China Medical University, Taichung 40402, Taiwan
}

Received: 6 October 2020

Accepted: 20 January 2021

\begin{abstract}
Cities and towns are affected by the multi-dimensional industrial activities with semi-arid and arid environments which cause a substantial rise in environmental pollution specifically in aquatic areas. The current study estimated the water quality and related health impacts by the consumption of heavy metal contamination. Surface water samples $(n=52)$ were collected using systematic random sampling technique from semi-arid region along Chenab river of district Sialkot, Gujrat and Mandi-bahwal-din of Punjab, Pakistan. Different physio-chemical and biological parameters and various heavy metal concentration were investigated using standard procedures from the collected surface water samples. Different physio-chemical and biological parameters and heavy metals concentration especially arsenic (As) and chromium (Cr) were above the permissible value of World Health Organization (WHO) and the National Environmental Quality Standards (NEQs). Water quality index results reflected that water quality of all samples were very poor and not suitable for the purpose of drinking. The value of Hazard Quotient (HQ) for As was near the threshold level (HQ>1) and carcinogenicity of As and Cr was $1 \times 10^{-4}$ in adults and children was more than the permissible limit laid down by WHO. Anthropogenic activities combined with semi-arid weather of the area in relation with diverse and uncommon water features triggered heavy metal pollution. Inverse distance weighted analyst module of ArcGIS software has been used to generate the spatial distribution of water pollutants of constituents.
\end{abstract}

Keywords: pollution, water quality index, physio-chemical, heavy metals, risk assessment

\footnotetext{
*e-mail: mujahid726@yahoo.com

**e-mail: shafaqataligill@yahoo.com

***e-mail: ayesha.siddiqua@uog.edu.pk
} 


\section{Introduction}

Water quality is the characteristics of water which defines the water for its beneficial use as well as the sustainability of environment. The quality of water in any environment provides significant information about the resources for supporting life in that environment and its suitability for consumption for human and other living organisms in the environment [1]. Globally, aquatic contamination has become a serious matter principally with increased urban growth [2-4]. It has significant effects over the management of aquatic resource in a number of ways like overexploitation of resources, industrialization, contamination and landuse change [5-8]. The untreated industrial and urban wastewater discharge has significant effect on the water resources, soil and plants [9-12], especially the heavy metals impact on the health of human beings and the surrounding ecosystem [13-16]. Increased level of heavy metals in water including $\mathrm{Cr}$, As, lead $(\mathrm{Pb})$, manganese $(\mathrm{Mn})$ and cadmium $(\mathrm{Cd})$ are toxic for human and aquatic life particularly their carcinogenicity and other related health issues such as breath shortening [17, 18].

Centralization of contamination expanded step by step from last couple of decades and affected the quality of water. The debasement of water bodies leads towards the deficiency of clean and drinking water and furthermore loss of common frameworks [19]. Current water reserves are insufficient and deterioration of freshwater quality cause grave water shortage particularly in underdeveloped and developing nations along with Pakistan [20-24]. About 70\% of extracted water consumed in irrigation practices [25]. Among the water scared areas by 2025, Pakistan is ranked on seventh highest region of the world. As per the response of farmers, the shortage of water also has great economic effects. Farmers continuously exercise several techniques in agriculture sector for adaptation to climate change vulnerability among them water shortage plays a key role [26, 27].

Anthropogenic activities deteriorated the quality of aquatic resources in many developing countries including Bangladesh, Pakistan, India and Africa [2830]. The South Asian region country like Pakistan with climatic conditions as arid and semi-arid in various zones. Due to increased urban population, a great extent of people is facing water associated issues [31]. In province Khyber Pakhtunkhwa, more than half of the six million population in various regions have no approach to safe drinking water because of increased metal contamination from nearby areas [32]. The groundwater aquifers are decreasing up to $3.5 \mathrm{~m}$ in the province of Sindh and Baluchistan, which is an alarming situation to the population living in these areas [33-35]. Various studies reported the quality of water among various cities of Punjab including Lahore (100\%), Multan (94\%), Sheikhupura (73\%), Bahawalpur (88\%), Gujranwala (64\%), and Kasur (100\%) where the As (Arsenic) is exceeding the permissible limit [36-38].
So, it is important to monitor the concentration of various contaminants and their related health impacts in surface water resources of remaining unexplored areas of Punjab, Pakistan. Internationally, health risk assessment by the use of various indices and statistical analysis in various water reserves have been stated earlier [39-41]. Water quality index (WQI) proved an easy method for the assessment of water quality in a numerical way. It converts the pollutants concentration to various sub-indexes and ultimately change these values into one numerical value, depending on their quality [42].

The present study was planned for the monitoring and evaluation of surface water quality for irrigation purposes to produce reliable agriculture products, also for determination of the surface water quality of the Chenab River, depending on WQI and to develop WQI maps associated with health effects caused by heavy metals contamination.

\section{Materials and Methods}

\section{Study Area}

The location of the study area was along Chenab river of district Sialkot, Gujrat and Mandi-bahwal-din (Fig. 1). This study area contains two Head Barrages, Head Marala and Head Khanki. Different seasonal drainage and main wastewater drainage entered in Chenab River from Sialkot industrial state, small industries of Gujrat and sugar industries from MandiBahwal-Din.

\section{Sample Collection, Preservation and Quality Assurance}

Water samples were collected in summer from fiftytwo sampling locations along the River Chenab with the help of systematic random sampling technique in an area of $2.5 \mathrm{Km}$. Collected samples were treated and preserved according to the guidelines described by American Public Health Association (APHA, 1995) and (ICARDA) standard methods [43].

\section{Analysis}

Collected samples were examined for the determination of heavy metal concentrations by Atomic Absorption Spectrophotometer (AAS) method reported elsewhere [44, 45].

Furthermore, the principal component analysis (PCA) for heavy metals and physicochemical parameter was also performed.

\section{Water Quality Index (WQI)}

To show expressive conclusion, Weighted Arithmetic model of WQI was used which was established by National Sanitation Foundation (NSF) in 1965 [46]. It is a numerical based model that transfer big data into 

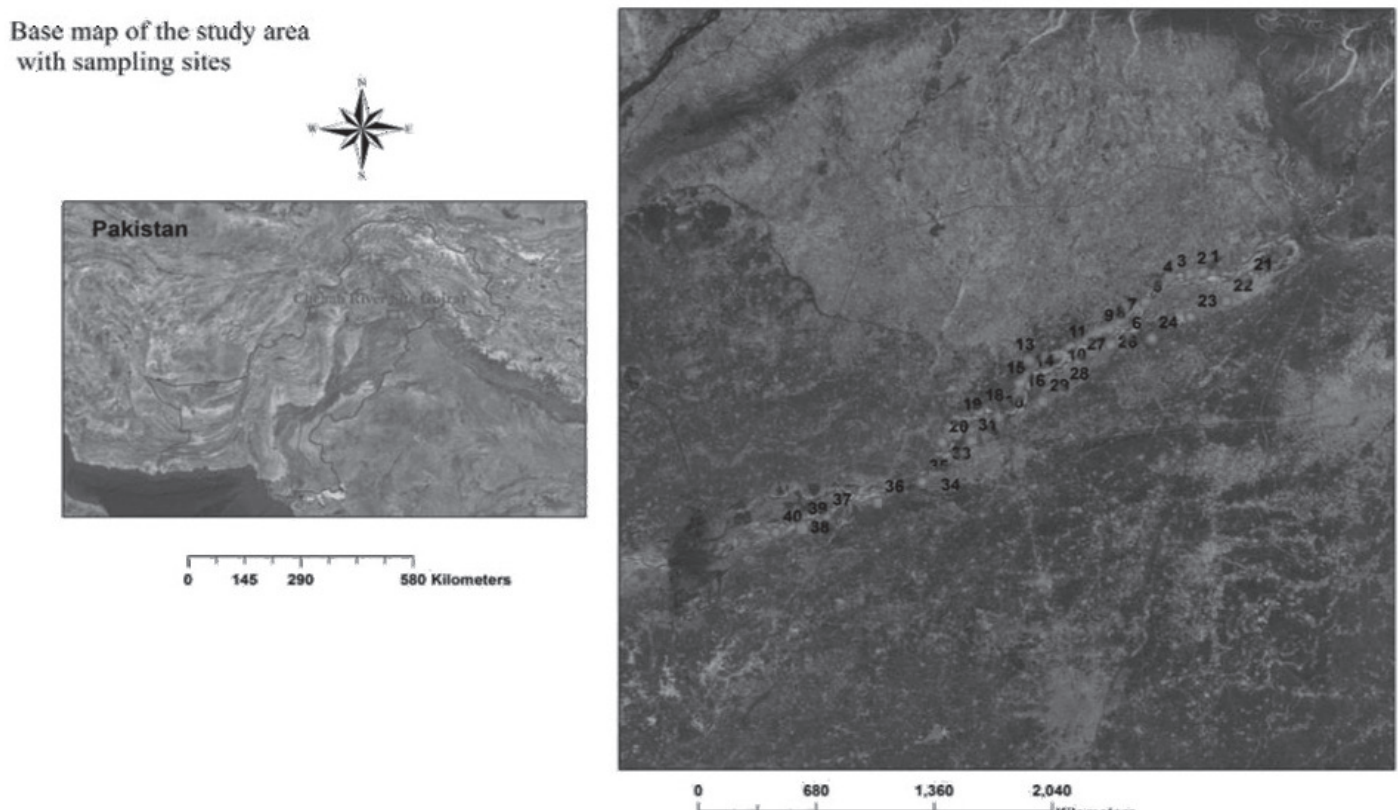

Fig. 1. Study Area and Sampling Sites.

only one value which represents the water quality of all samples. The equations for WQI is as given below;

Part I of WQI calculation:

$$
W i=\frac{w l}{\sum_{i=1}^{n} w i}
$$

...where:

$w i=$ weight of each parameter

$n=$ number of parameters

$W i=$ relative weight of each parameter

Part II of WQI calculation:

$$
\begin{aligned}
& q i=\frac{C i}{S i} * 100 \\
& q i=\frac{C i-V i}{S i-V i} * 100
\end{aligned}
$$

...where:

$q i=$ quality rating scale of each parameter

$\mathrm{Ci}=$ concentration of each parameter in water sample

$\mathrm{Si}=$ Quality Standard of each parameter

$V i=$ ideal value which is considered 7 for $\mathrm{pH}$ and 14.6 for DO

Final WQI is calculated by the following equation:

$$
W Q I=\sum W i * q i
$$

\section{Health Risk Assessment}

\section{Carcinogenic and Non-Carcinogenic Exposure}

There are numerous routes of exposure for heavy metals into the body of human beings, it may be through dermal interaction, oral ingestion, and inhalation [47]. Average daily dose (ADD) was evaluated with the help of given formula

$$
\mathrm{ADD}=\frac{\text { IR X C X ED X CF XEF }}{\text { ATXBW }}
$$

As per [48, 49], the concentration of metal is denoted by $\mathrm{C}$ in $(\mathrm{mg} / \mathrm{L})$, IR is the rate of water intake which is $0.63 \mathrm{~L}_{\text {day }}{ }^{-1}$ for children and $2 \mathrm{~L} \mathrm{day}^{-1}$ for adults, $15 \mathrm{~kg}$ average body weight (BW) was taken for children while for adults it was taken as $72 \mathrm{~kg}$. [50] expresses exposure frequency (EF) as 350 days/year, exposure duration (ED) for children was presented 6 years and in case of adults it was 70 years and the 25,550 days was taken as the average time (AT) for adults and for the children AT was 2190 days in case of non-carcinogenic risk assessment (NCRA), while it is 25,550 days for both children and adult in case of carcinogenic risk assessment (CRA) [51].

In order to assess the value of NCR, the hazard quotient (HQ) of ADD was evaluated, which was taken as threshold limit value. It was measured by dividing the ADD with oral reference dose (RfD) [52].

$$
\mathrm{HQ}=\frac{\mathrm{ADD}}{R f D}
$$

Carcinogenic risk (CR) describes the probability measured in percentage (of populations) in $\mathrm{m} \mathrm{kg}^{-1} \mathrm{day}^{-1}$. $\mathrm{CR}$ is the likelihood of cancer risk to occur for lifetime. It is evaluated by multiplying both carcinogenic slope factor (CSF) and lifetime average daily dose (LADD). Here, LADD is evaluated by taking an average time of 25,550 for adults and children as well [51]. 10-3 risk 
value indicate the high risk of cancer [52]. CR is only calculated for $\mathrm{Cr}$, Ni and As because of the lack of accessibilities of CSF values.

$$
\mathrm{CR}=\mathrm{CSF} \times \mathrm{LADD}
$$

\section{GIS Analysis}

GIS assists in better representation of ecosystem and its complex datasets regarding climatic fluctuations, prevailing environmental conditions, spatiotemporal variations, etc. For this reason, at the time of sample collection latitude and longitude of sampling sites were also recorded with the help of Garmin eTrex GPS. The coordinate points along with their analyzed results were exported to ArcGIS software as a point layer file. Metadata of each sample after coding were stored in the point attribute table. To delineate the spatial behavior of water quality, spatial analyst tool was used. An interpolation technique through Inverse Distance Weighted (IDW) was applied to prepare thematic layer map of each parameter for the Chenab River.

\section{Results and Discussion}

Surface water samples $(\mathrm{n}=52)$ from diverse sites were assessed for physiochemical, bacteriological parameters and values of heavy metal. Average concentrations of all water parameters are given in Table 1 for heavy metals and in Table 2 for physiochemical parameters. Concentration of various heavy metals and physiochemical parameters also depicted in thematic layered maps in Fig. 3 (A-G) and $4(\mathrm{~A}-\mathrm{N})$.

The values of physical parameters in river water were as pH (9.8 \pm 8.4$)$, chloride (289.187 \pm 251.837$)$, TDS $(1765 \pm 1200)$, calcium + magnesium $(128 \pm 56)$, turbidity
(9 \pm 5$)$, electrical conductivity $(292 \pm 109)$. These values were found much greater than their allowable standard limits. Greater amount of $\mathrm{pH}$ in surface water may become a reduction in the harmful effects of heavy metals [54]. Industrial waste and sewage discharge were the basic source of increased value of TDS in river water $[55,56]$. Increased concentration of TDS may enhance the values of BOD and COD in water which eventually affect the value of DO (dissolve oxygen), which cause irritation in gastrointestinal system, erosion and change in taste etc. [57, 58]. As per Kattan et al. [59], the increased concentration of chloride may cause hypertension and rise in blood pressure, it also changes the water taste and generate osmotic pressure in marine living organisms. The PCA results are presented in the Fig. 2.

Biological parameters including $E$. coli and total coliforms in the river water were much greater than NEQS and WHO allowable standards $(0 / 100 \mathrm{~mL})$. River waters are very contaminated due to various man-made activities in urban areas of Pakistan like Karachi, Lahore, Rawalpindi, Kasur, Sialkot, Peshawar, Gujrat and Faisalabad and not recommended for human consumption $[31,60,61]$. Pakistan council of research in water resources (PCRWR) conducted a study in 2005 in urban areas of Pakistan and gave a statement that $65 \%$ and $35 \%$ of groundwater samples were polluted with total coliform and E. coli, respectively, whereas surface water samples had $100 \%$ bacterial contamination of $E$. coli and total coliform bacteria. Khan et al. [62] studied pathogenic contamination of river Swat in Pakistan, and found increased fecal contamination in river water due to the discharge of municipal effluents in surface water, urbanization, agricultural runoffs and human excreta responsible for different diseases in native public.

Surface water samples contain As $(0.094 \pm 0.051)$ and $\mathrm{Cr}(0.092 \pm 0.021)$ higher than their allowable standards. According to Noreen et al. [63] the basic
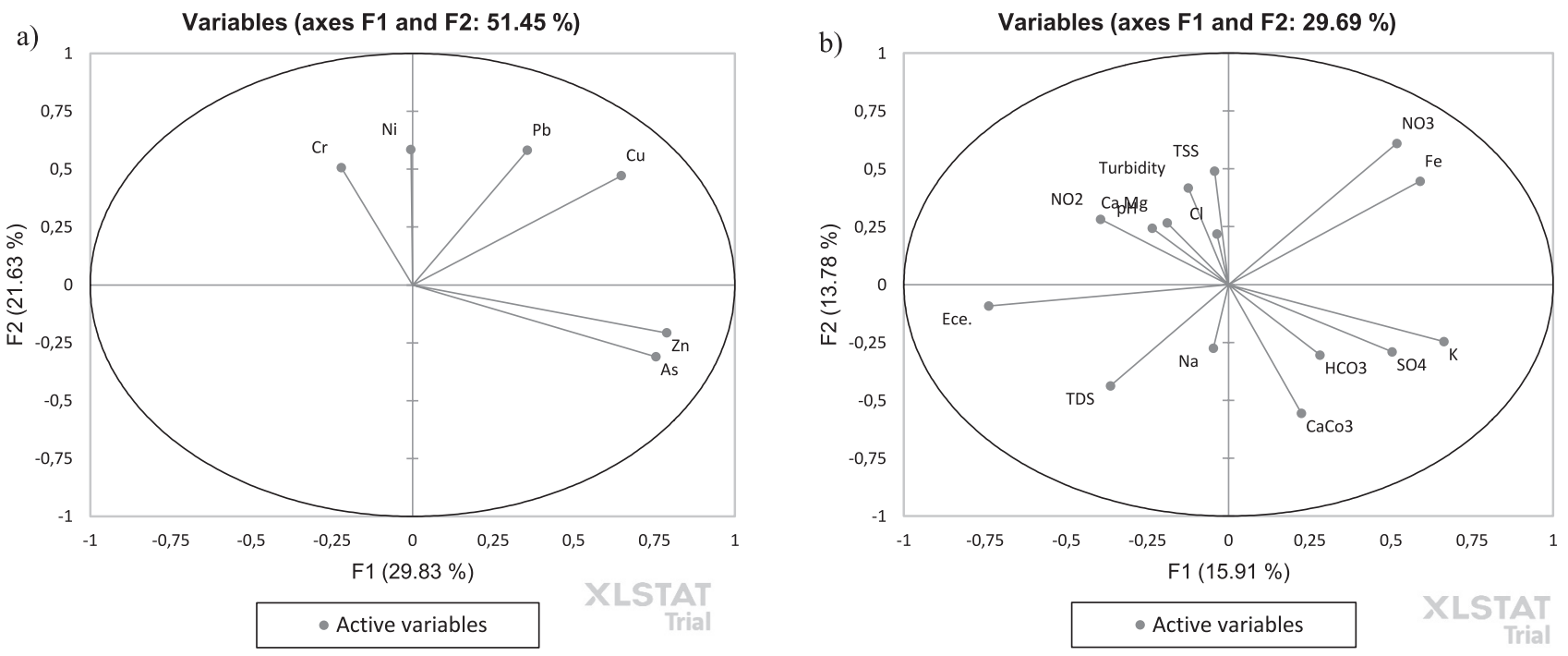

Fig. 2. PCA for the heavy metals a) and other variables b) studied in this study. 


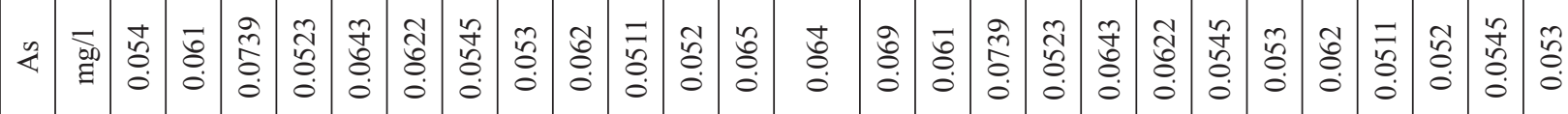

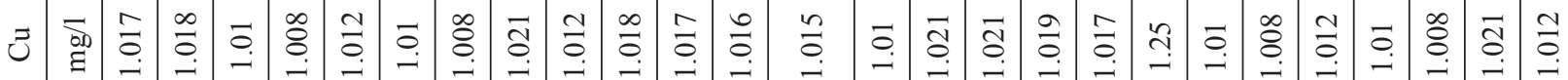

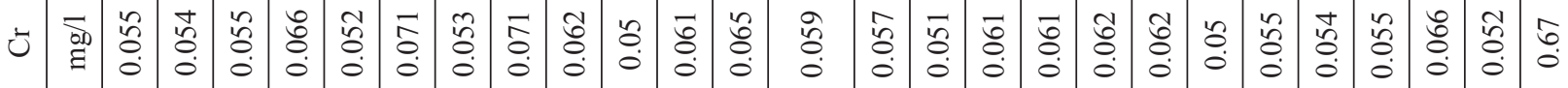

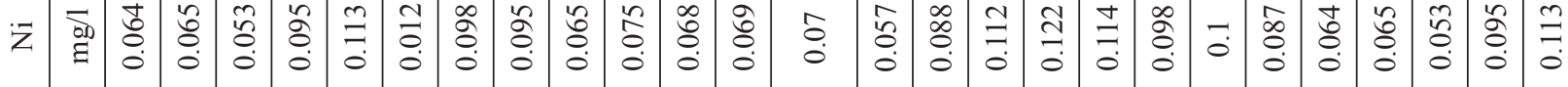

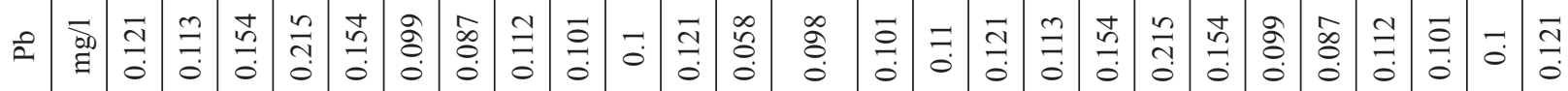

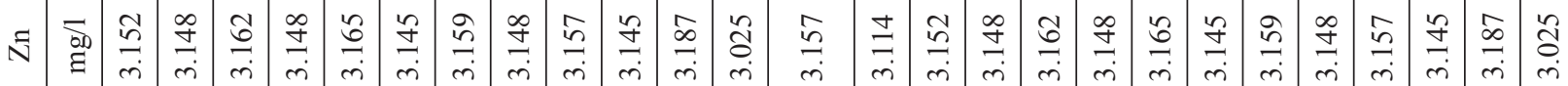

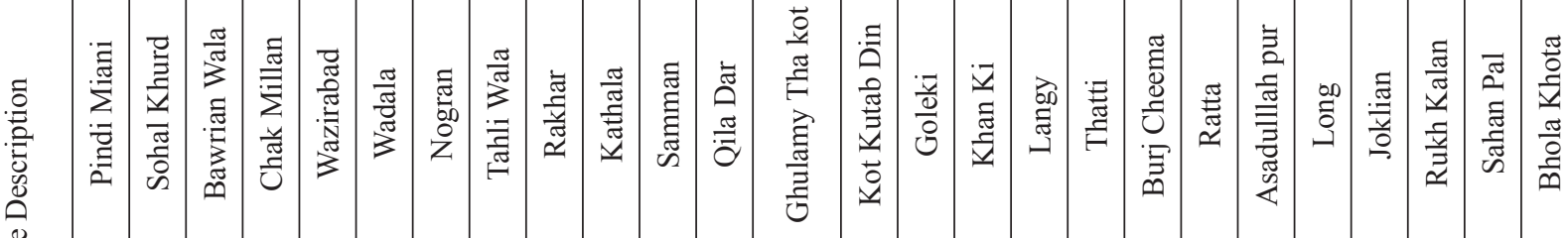
言

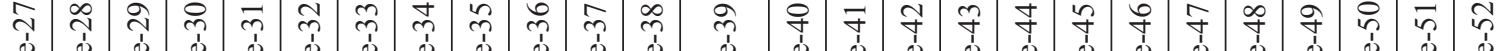

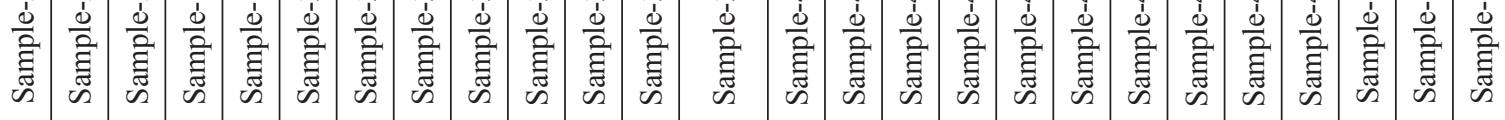

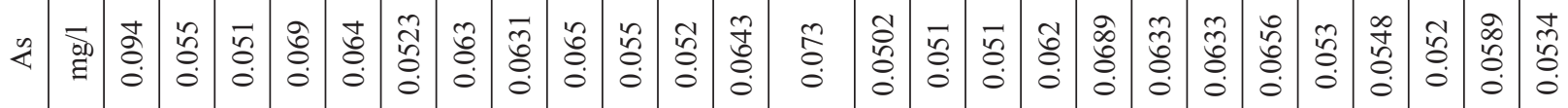

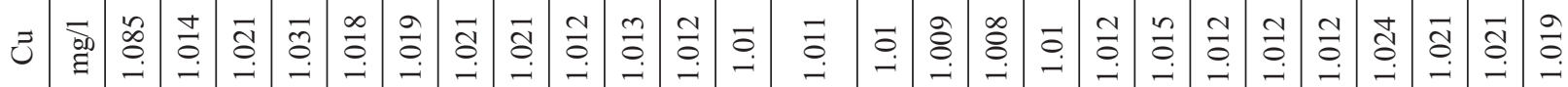

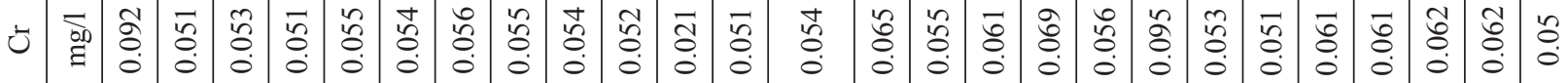

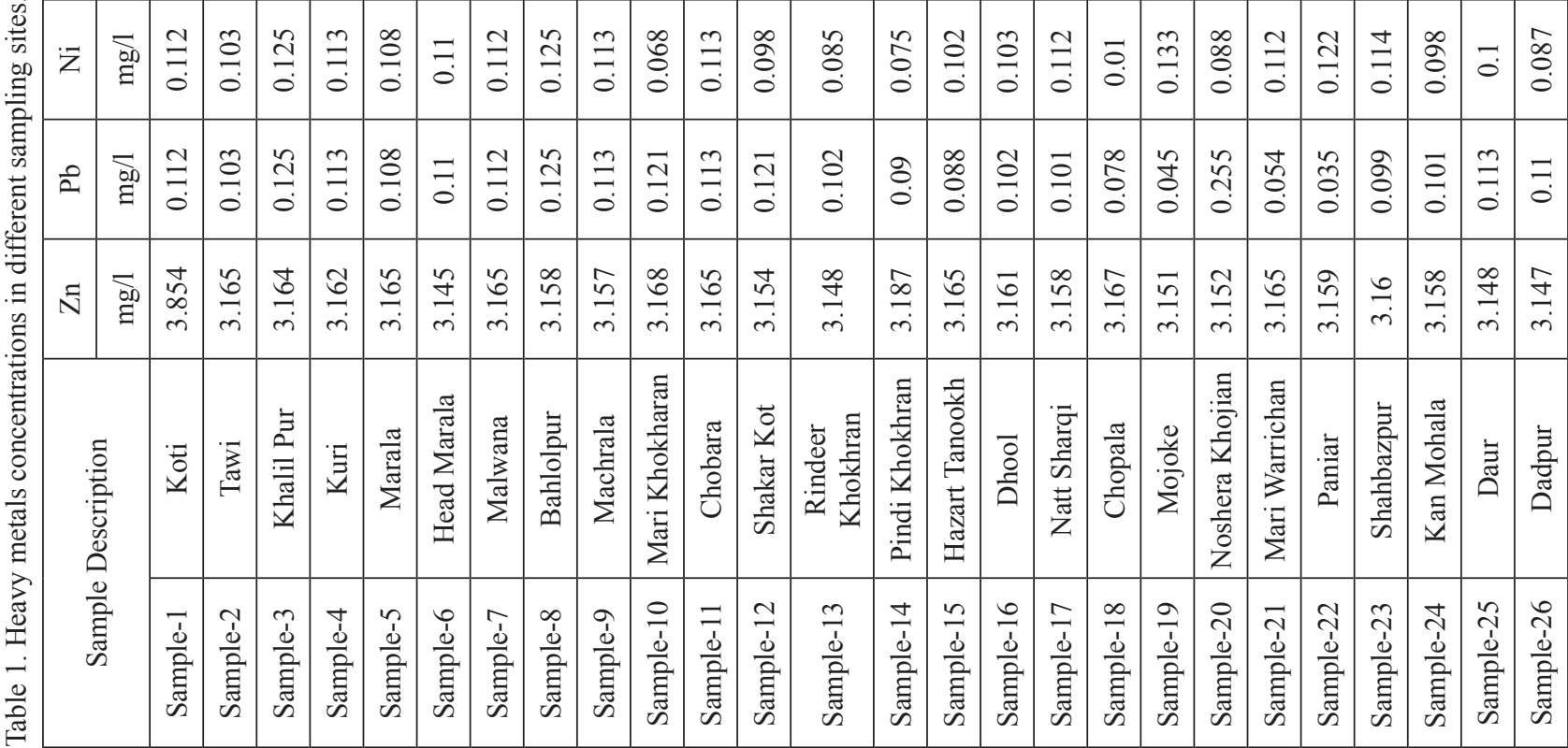




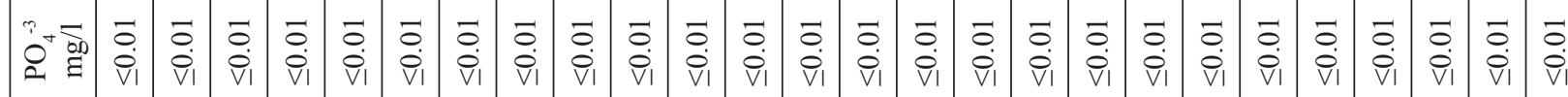

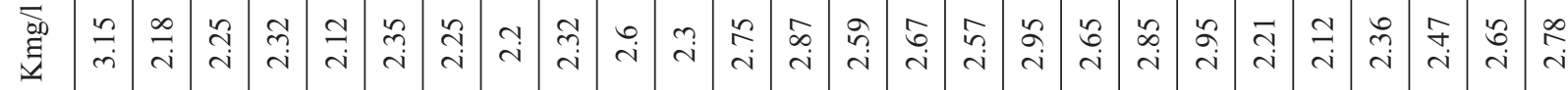

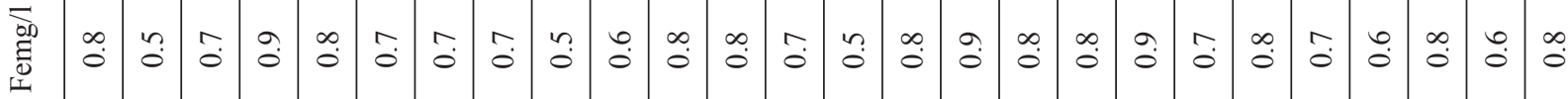

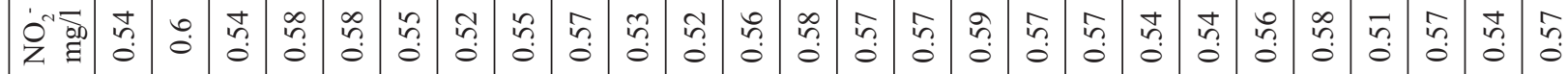

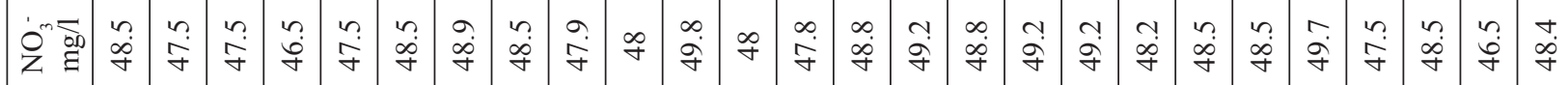

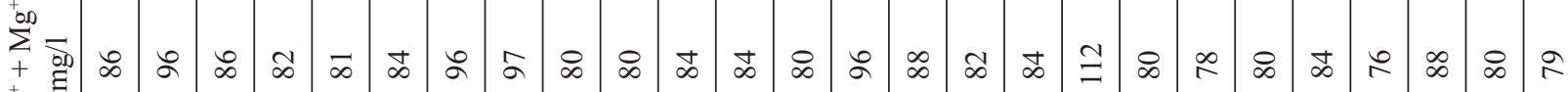
שீ

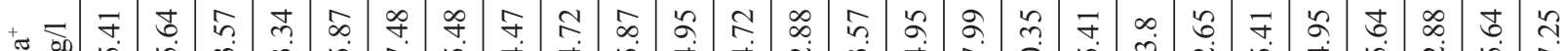

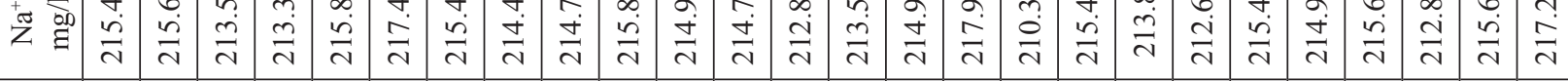

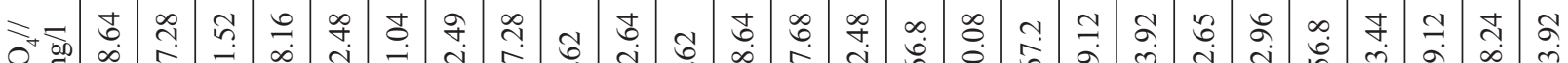

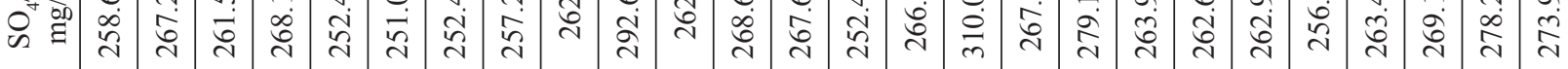

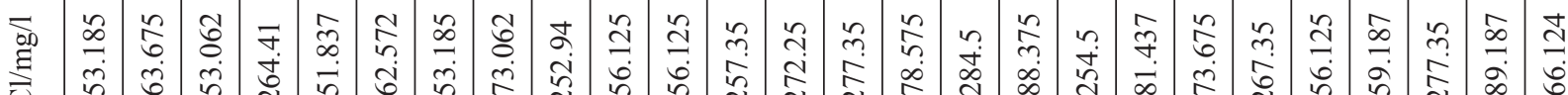
U तु

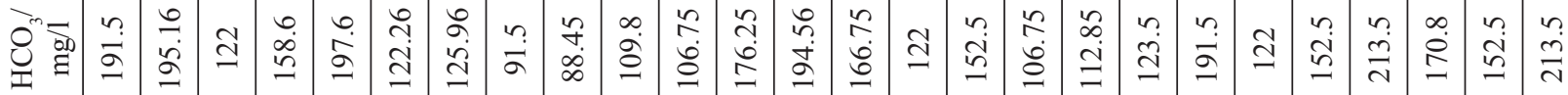

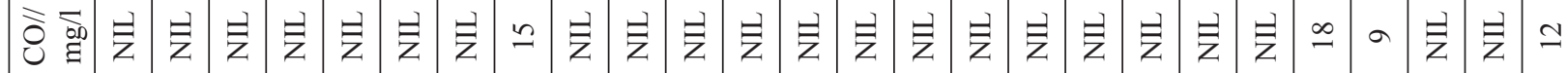

?.

z $\dot{\mathrm{s}}$

?

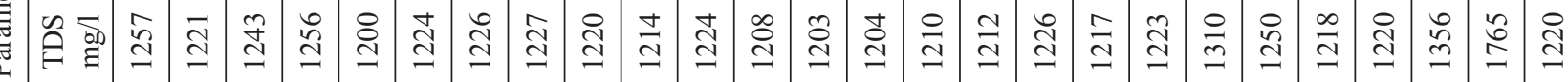

\begin{tabular}{|c|c|c|c|c|c|c|c|c|c|c|c|c|c|c|c|c|c|c|c|c|c|c|c|c|c|}
\hline $\begin{array}{ll}n & 5 \\
\hat{H} & \vdots\end{array}$ & $\stackrel{n}{2}$ & $\tilde{n}$ & 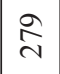 & $\ddot{\infty}$ & ڤे & त & $\stackrel{\circ}{\sim}$ & $\stackrel{n}{\stackrel{\sim}{\sim}}$ & 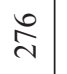 & $\begin{array}{c}\widetilde{D} \\
\text { N }\end{array}$ & $\overline{\vec{\lambda}}$ & 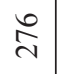 & $\stackrel{g}{\mathrm{~g}}$ & $\stackrel{\infty}{\infty}$ & $\stackrel{\sim}{\stackrel{\sim}{\nu}}$ & I & $\stackrel{\overbrace{}}{\tilde{\nu}}$ & $\stackrel{\infty}{\sqsubseteq}$ & $\stackrel{\infty}{ \pm}$ & $\stackrel{\infty}{\circ}$ & $\stackrel{\infty}{\subseteq}$ & 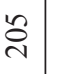 & $\stackrel{g}{\Xi}$ & $\begin{array}{l}\infty \\
n \\
n\end{array}$ & $\underset{-}{d}$ \\
\hline T & $\begin{array}{l}\infty \\
\infty \\
\infty\end{array}$ & $\stackrel{\sim}{a}$ & $\mid \begin{array}{l}0 \\
\infty \\
\infty\end{array}$ & $\begin{array}{l}0 \\
\infty \\
\infty\end{array}$ & $\begin{array}{l}\infty \\
\infty\end{array}$ & $\begin{array}{l}0 \\
\infty \\
\infty\end{array}$ & $\begin{array}{l}0 \\
\infty\end{array}$ & $\begin{array}{l}0 \\
\infty \\
\infty\end{array}$ & $\stackrel{0}{\infty}$ & $\stackrel{0}{\infty}$ & $\begin{array}{l}\infty \\
\infty \\
\infty\end{array}$ & $\underset{\infty}{+}$ & $\begin{array}{l}\infty \\
\infty \\
\infty\end{array}$ & $\begin{array}{l}\infty \\
\infty \\
\infty\end{array}$ & $\begin{array}{l}0 \\
\infty \\
\infty\end{array}$ & ă & \begin{tabular}{l|l}
0 & $\alpha$ \\
$\infty$ & $\alpha$
\end{tabular} & $\begin{array}{l}\infty \\
\infty \\
\infty\end{array}$ & $\infty$ & กั. & $\stackrel{0}{\infty}$ & $\underset{\infty}{\infty}$ & $\begin{array}{l}\infty \\
\infty \\
\infty\end{array}$ & $\underset{\infty}{\infty}$ & $\stackrel{b}{\infty}$ \\
\hline $\begin{array}{l}0 \\
0\end{array}$ & ڤె & $\stackrel{\nabla}{\sim}$ & $\underset{\sim}{0}$ & $\stackrel{\infty}{\stackrel{\infty}{v}}$ & $\vec{\sim}$ & ڤે & $\stackrel{n}{\sim}$ & 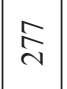 & గ్ర & $\underset{\sim}{\sim}$ & $\vec{\beth}$ & 。 & $\cong$ & $\stackrel{\text { g }}{ \pm}$ & 正 & 昌 & $\stackrel{m}{\varrho}$ & - & 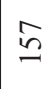 & 先 & $\bar{N}$ & $\tilde{n}$ & $\delta^{2}$ & $\stackrel{4}{5}$ & 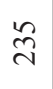 \\
\hline 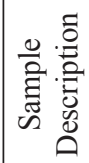 & \begin{tabular}{|l|}
$\vec{j}$ \\
$\vec{a}$ \\
$\overrightarrow{\tilde{n}}$ \\
$\tilde{n}$
\end{tabular} & 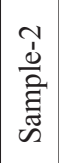 & $\begin{array}{l}\hat{j} \\
\hat{\tilde{d}} \\
\overrightarrow{\tilde{Z}} \\
\tilde{n}\end{array}$ & 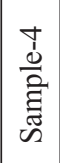 & 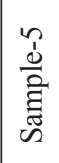 & 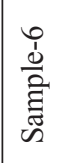 & 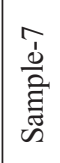 & 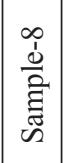 & 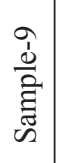 & 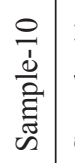 & 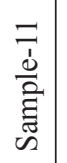 & 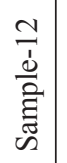 & 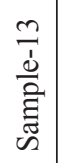 & 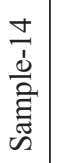 & 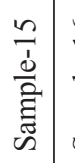 & 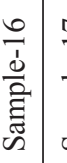 & 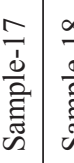 & 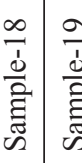 & $\begin{array}{l}\stackrel{\Upsilon}{1} \\
\stackrel{1}{n}\end{array}$ & 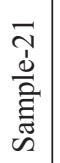 & 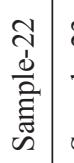 & 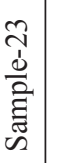 & 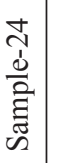 & & 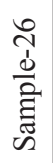 \\
\hline
\end{tabular}




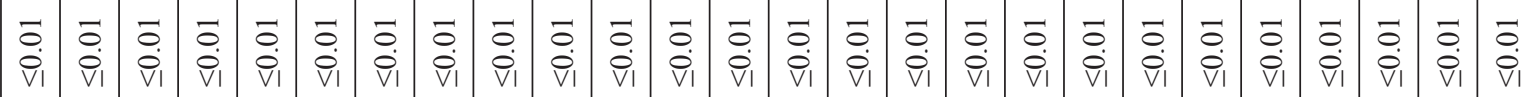

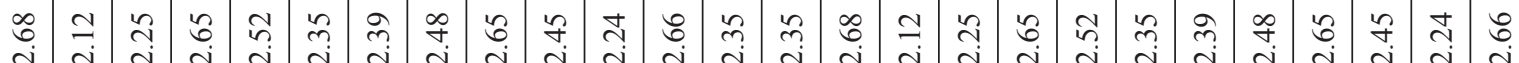

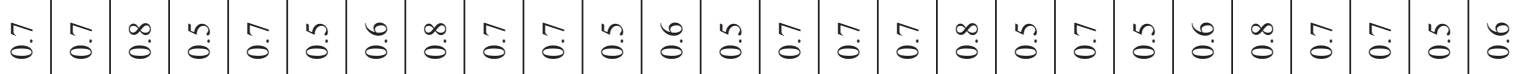

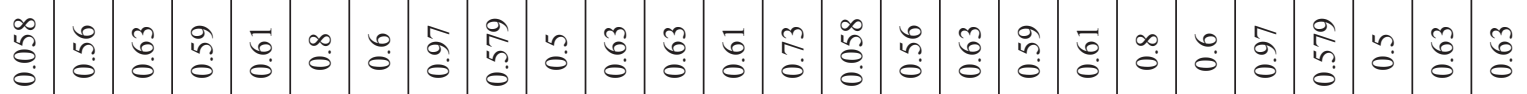

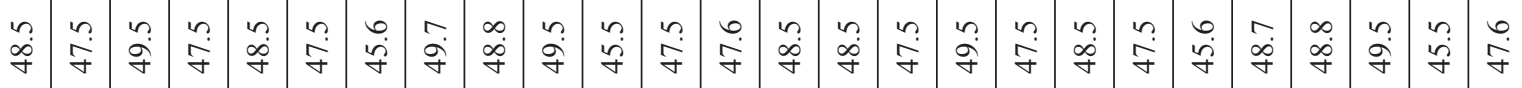

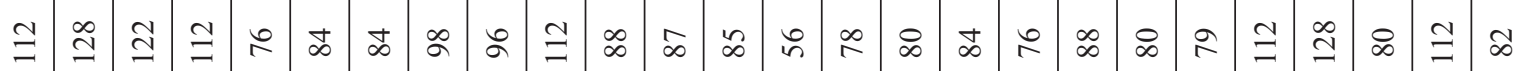

\&

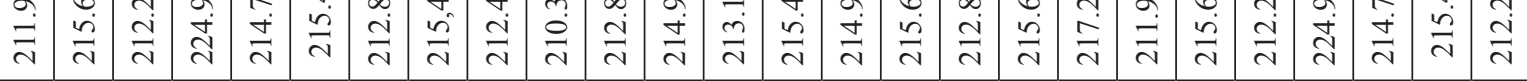

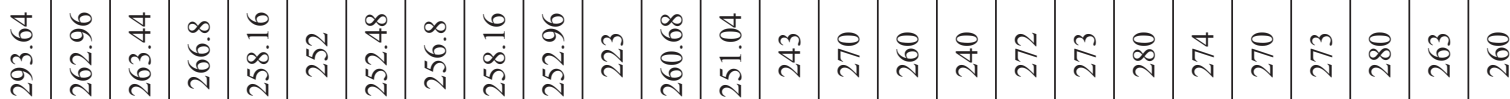

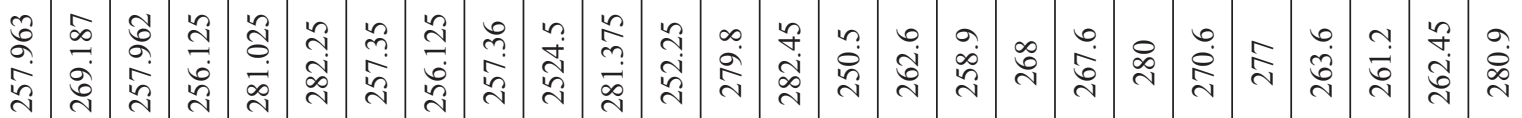

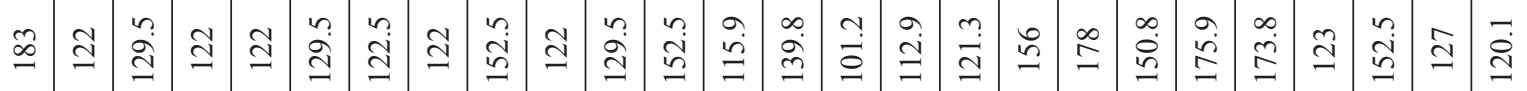

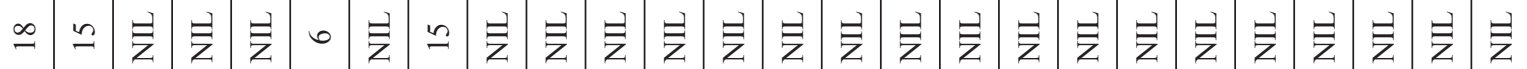

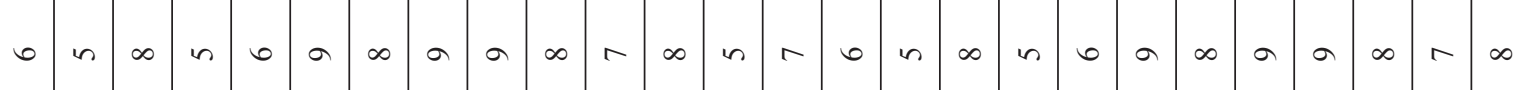

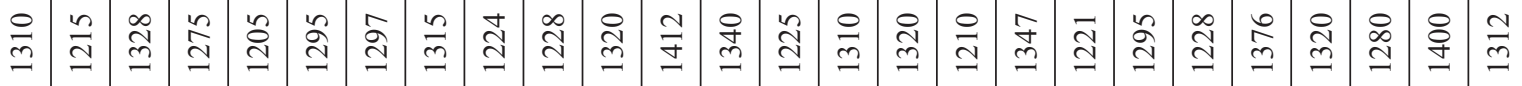

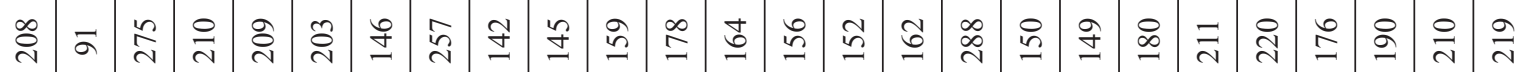

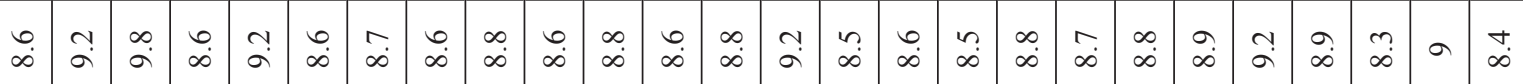

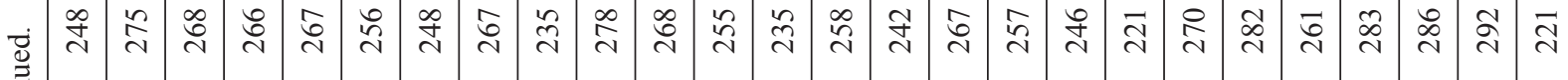

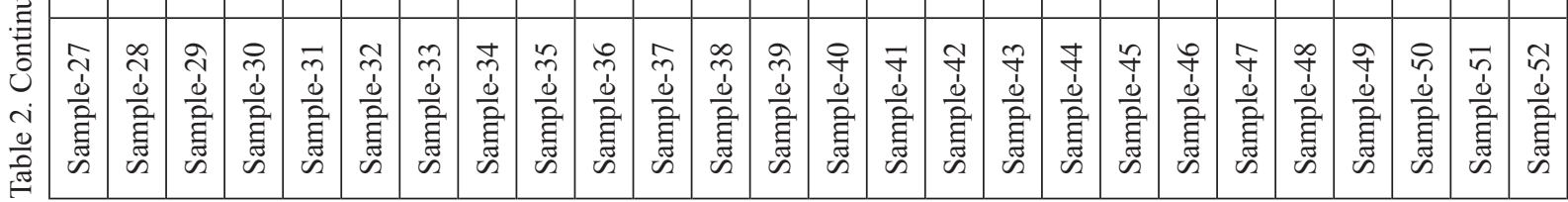



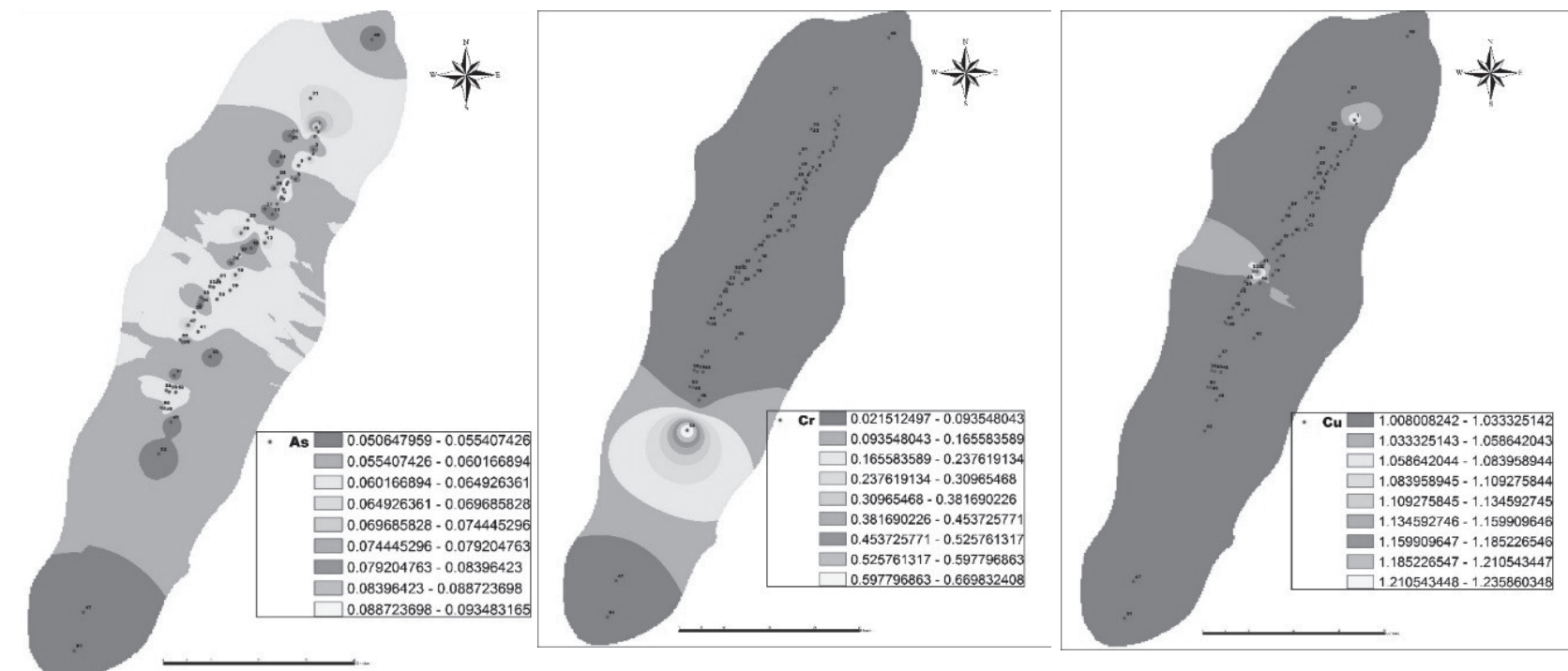

$3^{A}: A s$

$3^{B}: C r$

$3^{C}: C u$

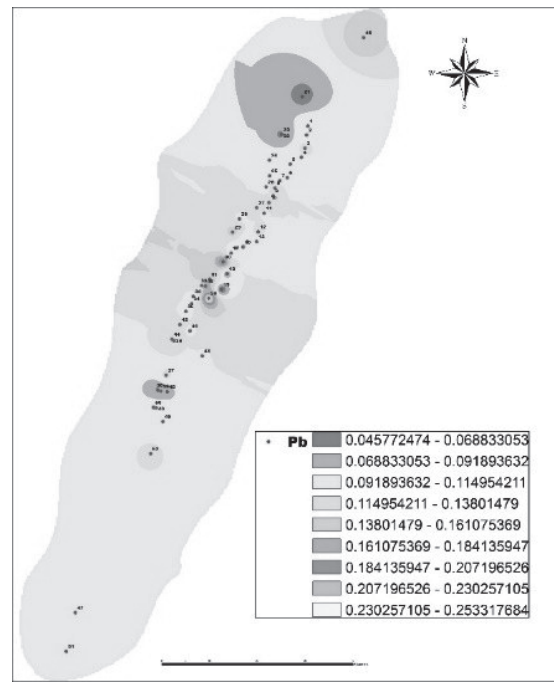

$3^{D}: P b$

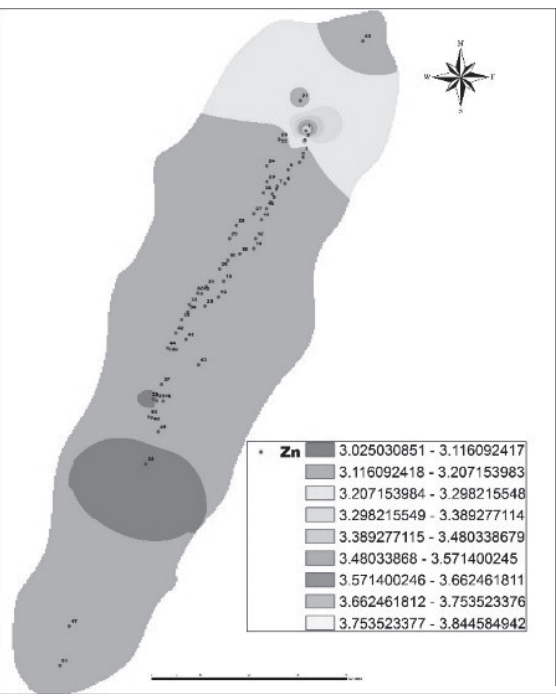

$3^{E}: Z n$
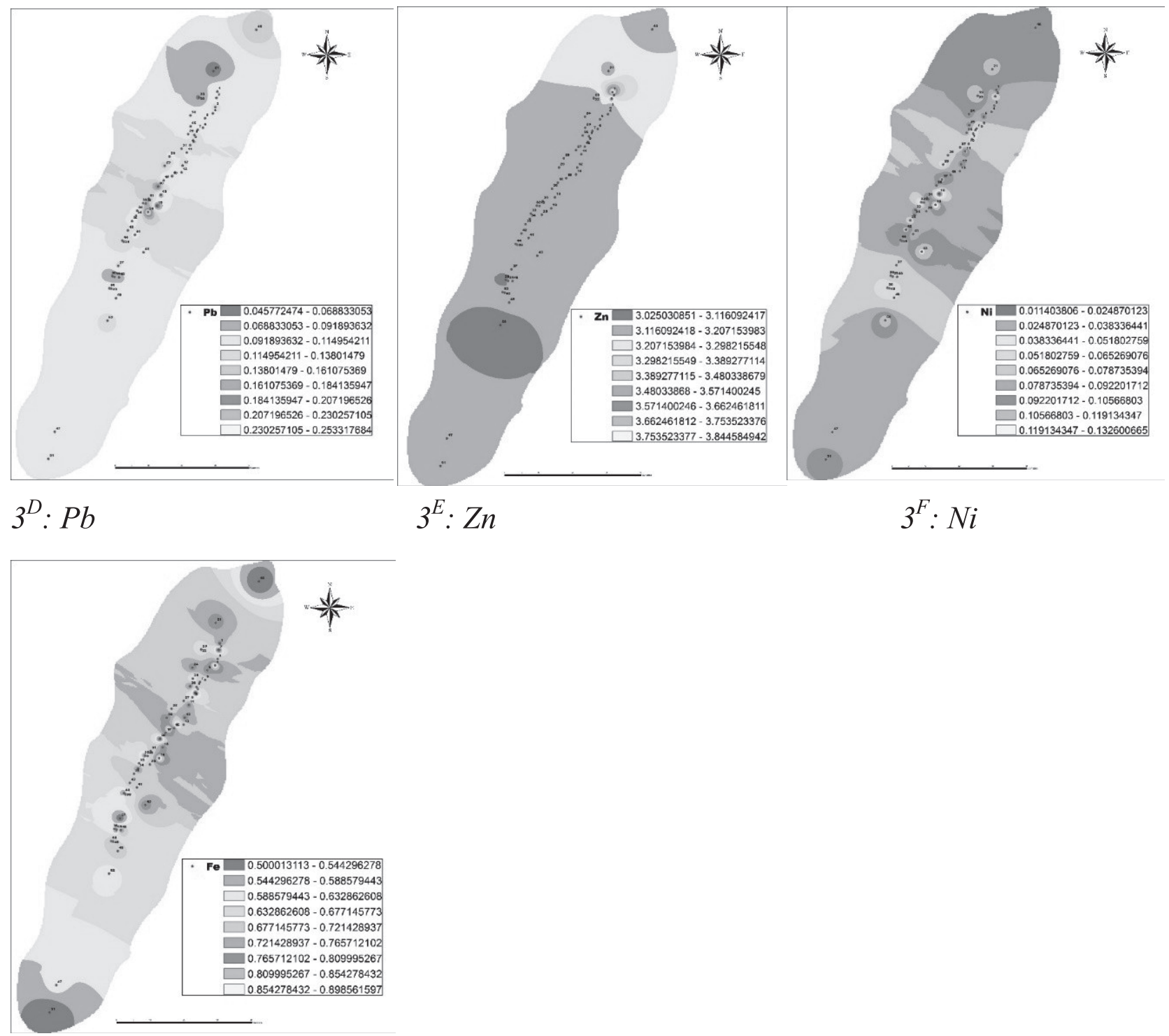

$3^{G}: \mathrm{Fe}$

Fig. 3. The thematic layer map of various heavy metals concentrations for River Chenab is given as As (A), $\mathrm{Cr}(\mathrm{B}), \mathrm{Cu}(\mathrm{C}), \mathrm{Pb}(\mathrm{D}), \mathrm{Zn}$ (E), Ni (F) and Fe (G). 


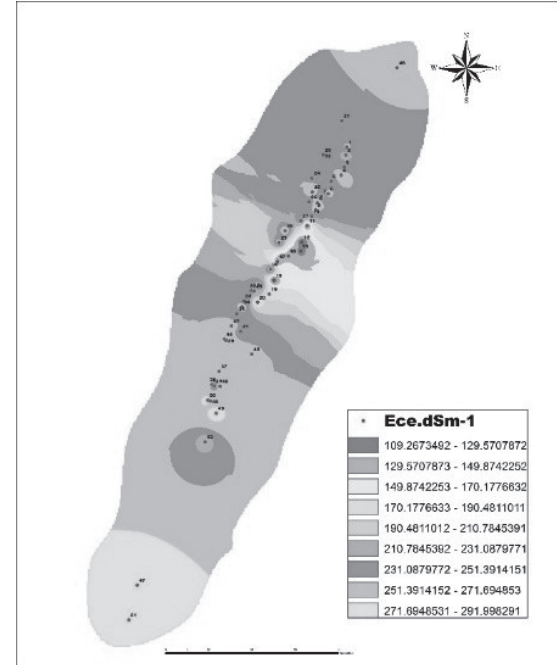

$4^{A}: E C$

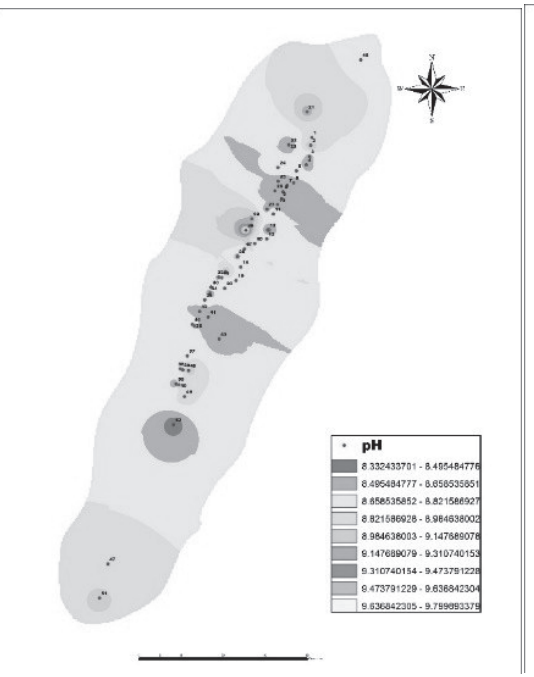

$4^{B}: p H$

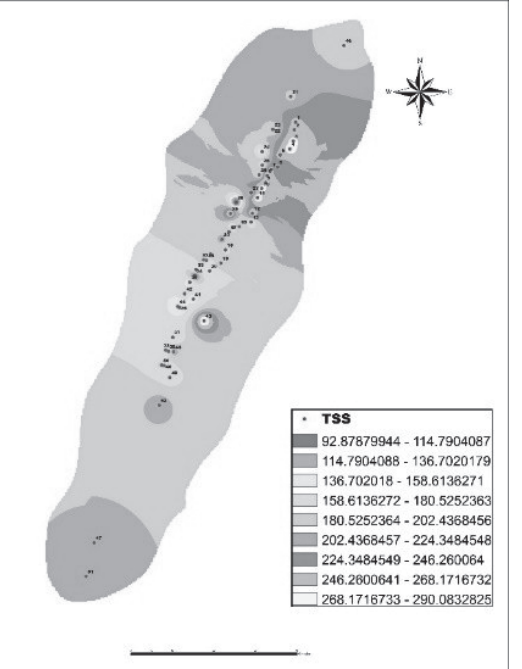

$4^{C}:$ TSS
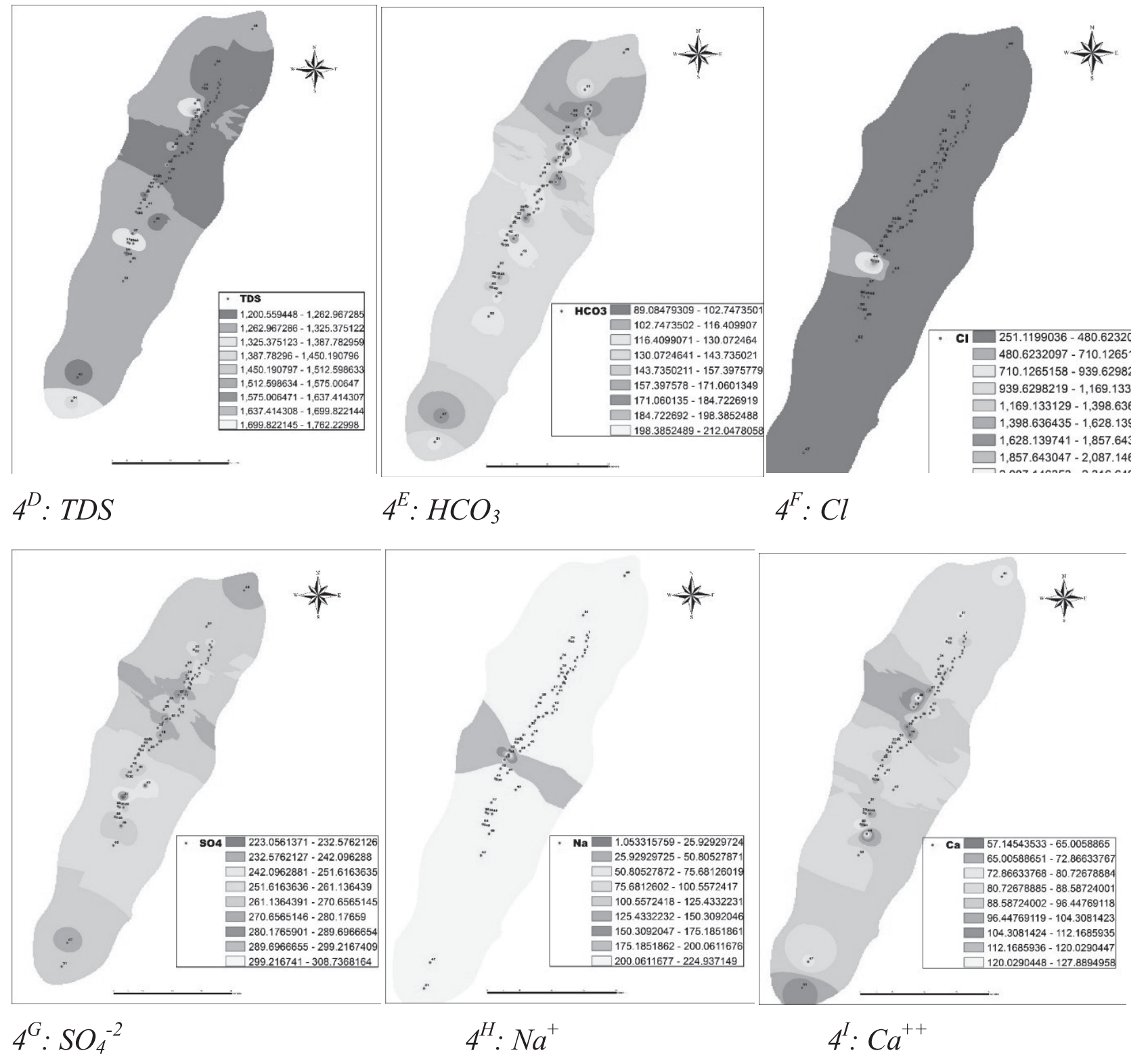

Fig. 4. The thematic layer map of various heavy metals concentrations for River Chenab is given as EC (A), pH (B), TSS (C), TDS (D), $\mathrm{HCO}_{3}(\mathrm{E}), \mathrm{Cl}(\mathrm{F}), \mathrm{SO}_{4}^{-2}(\mathrm{G}), \mathrm{Na}^{+}(\mathrm{H}), \mathrm{Ca}^{++}(\mathrm{I}), \mathrm{No}_{3}(\mathrm{~J}), \mathrm{No}_{2}(\mathrm{~K}), \mathrm{K}(\mathrm{L})$, Turbidity $(\mathrm{M})$, and $\mathrm{CaCO}_{3}(\mathrm{~N})$. 


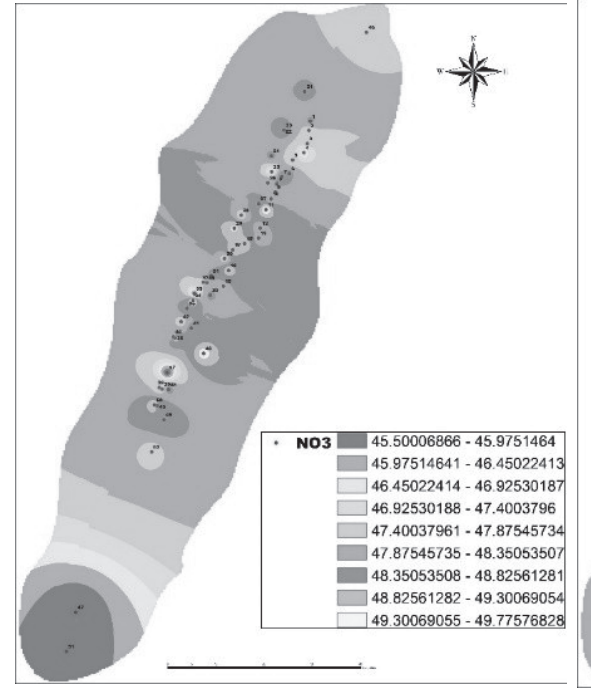

$4^{\mathrm{J}}: \mathrm{No}_{3}$

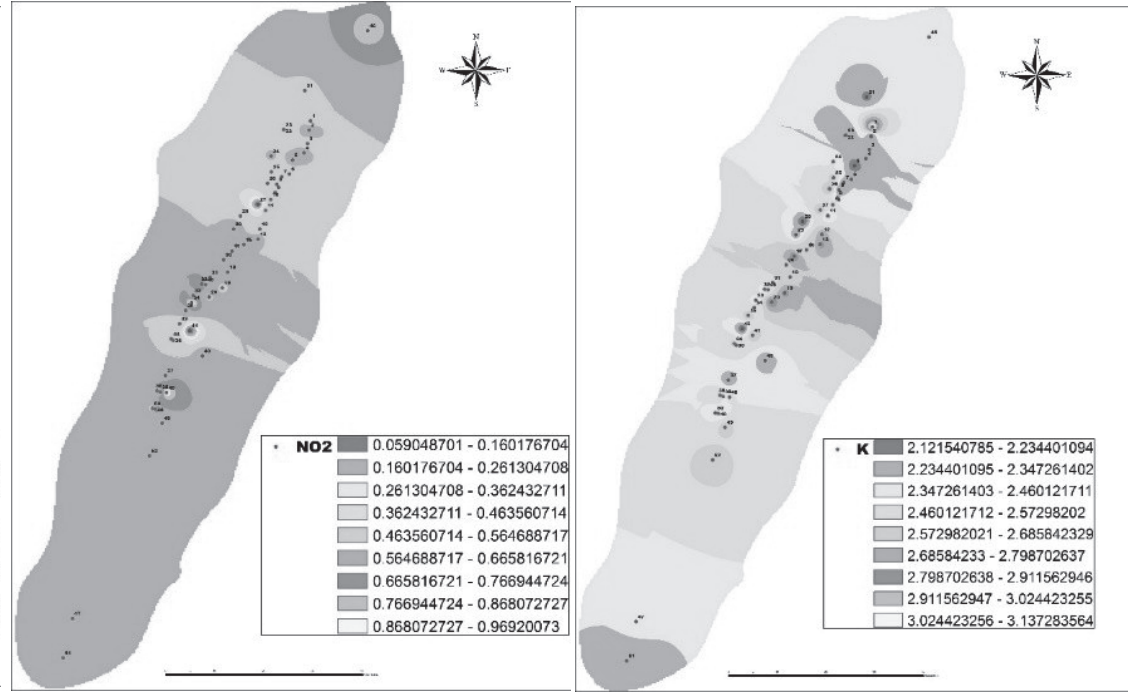

$4^{K}: \mathrm{No}_{2}$

$4^{L}: K$
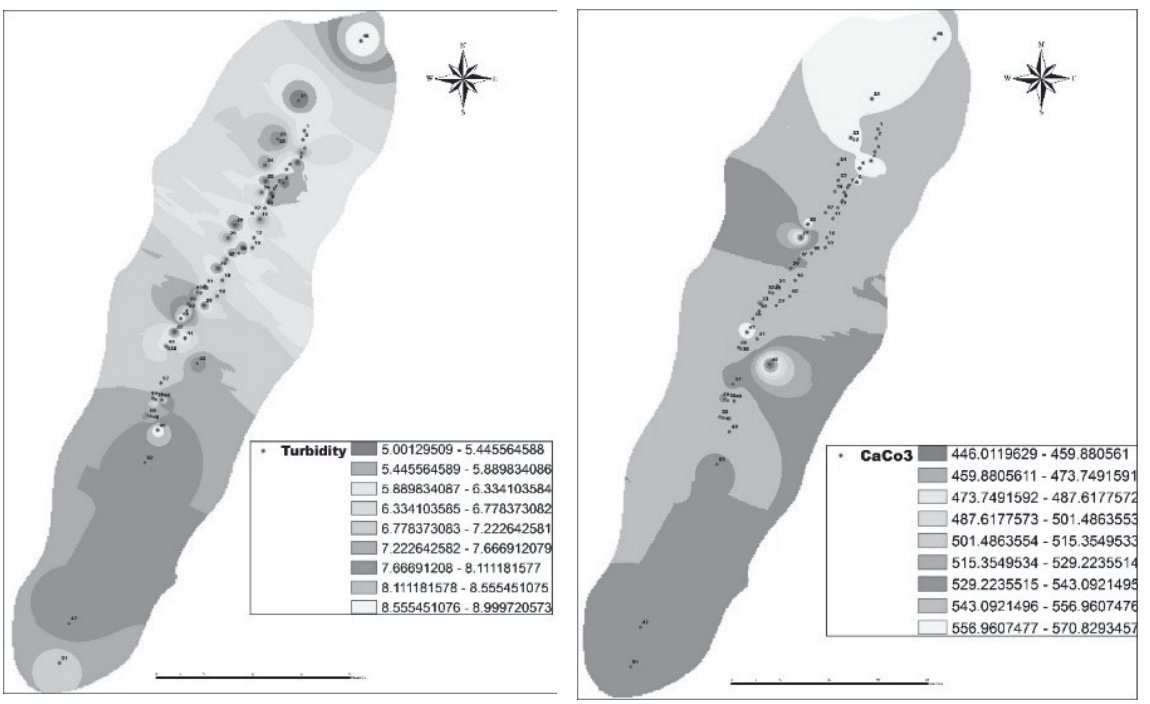

$4^{M}:$ Turbidity

$4^{N}: \mathrm{CaCO}_{3}$

Fig. 4. Continued.

reason of heavy metal contamination were manmade activities that affect the quality of water. Muhammad [18] stated that intake of Ni-chloride and Ni-sulphate can cause many health effects like fatal cardiac arrest. Rafiq et al. [64] determined that in various international and national environmental and health organizations, it is accepted that As is the basic lethal pollutants which cause many health effect and pose extreme environmental risk. Shahid et al. [65] stated that exposure to As (both chronic and acute) results in As related sickness known as arsenicosis and its toxic effect on health greatly related to the consumption rate of the vulnerable population. Many researchers reported an increased amount of As in the groundwater table due to biogeochemical, geothermal and geohydrological factors, stated As is mobilized in aquifers by many arsenic-causing oxides [66-71]. Nonpoint sources of heavy metals like atmospheric deposition could be considered too for increased concentration of pollution in surface water and heavy metals seepage in various resources of underground water [72]. In the current study, all the samples were collected from surface water of Chenab river, the potential cause of heavy metal pollution might be the industrial effluents and agricultural runoff along with atmospheric deposition usually in rainy seasons [73]. However, because of overpopulation and high industrialization, underground water contamination also increased with time [74, 63, 72]. The total amount of As was greater than those in other various countries but less than in different studies of Pakistan. Anthropogenic activities are the root cause of increased concentration of heavy metals like agriculture runoff and industrial effluent [75]. 


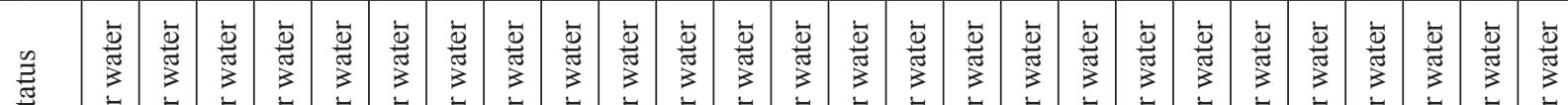

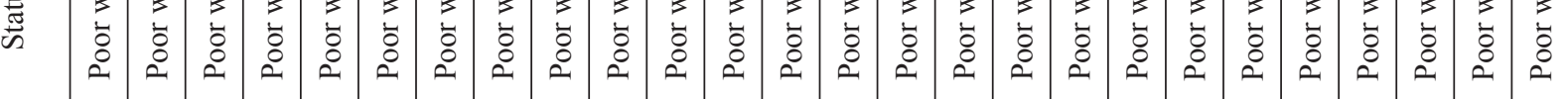

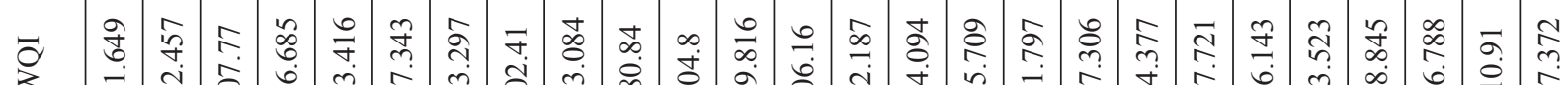

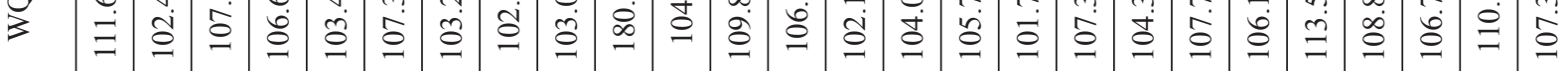

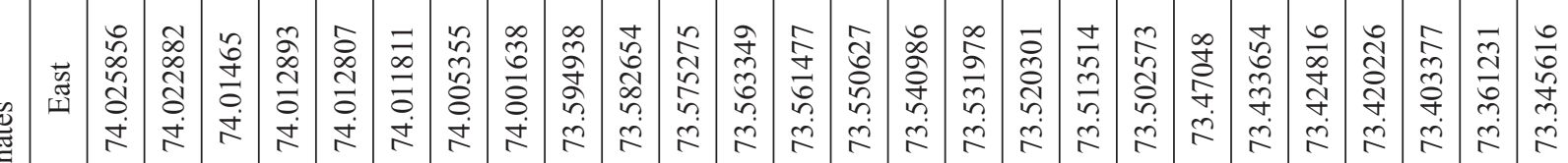

른

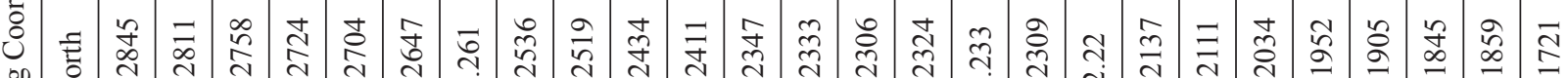

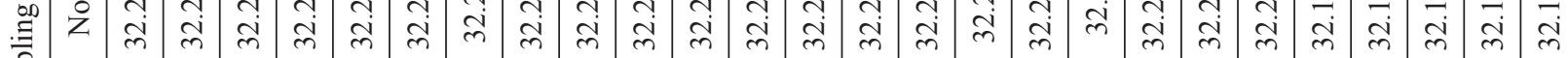

寣

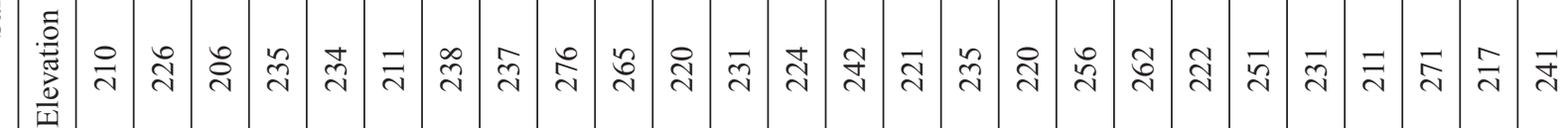

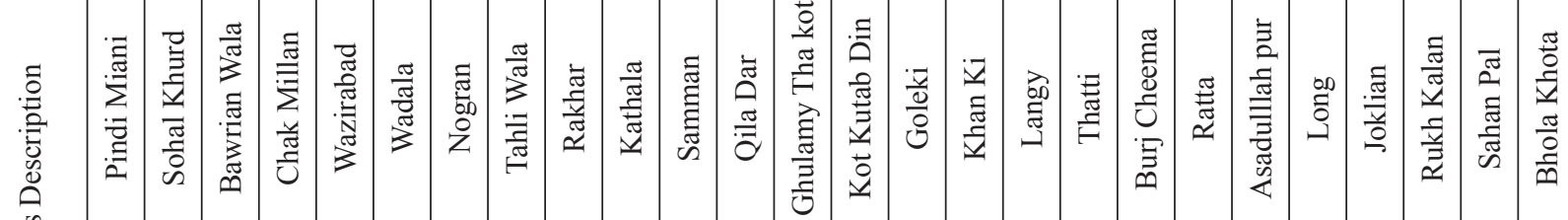

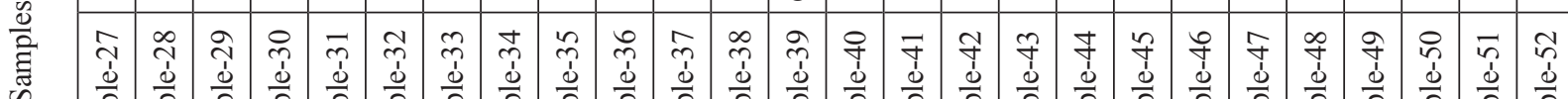

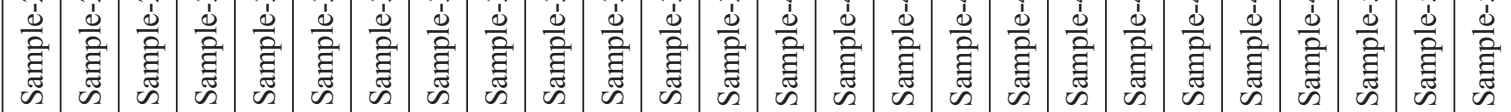

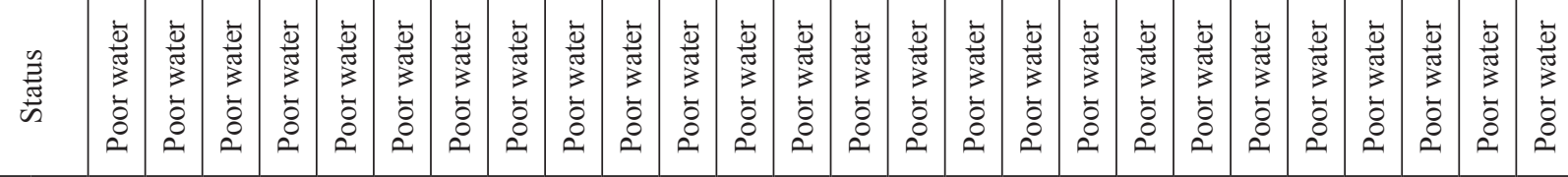

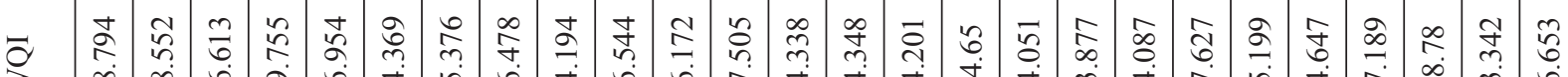

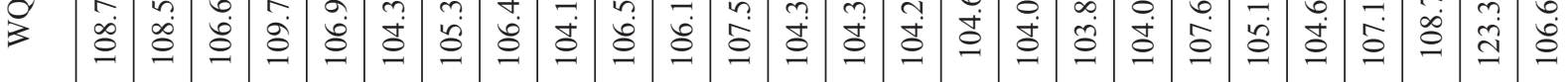

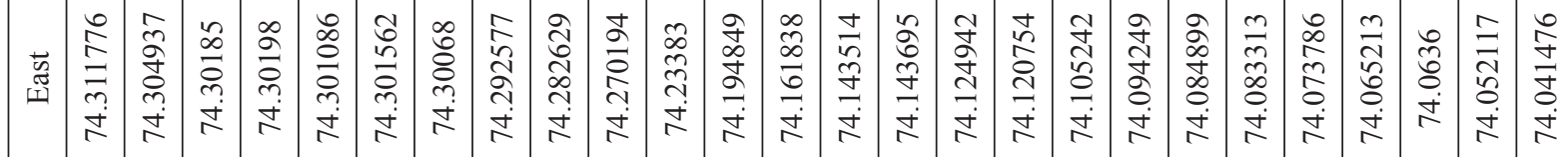

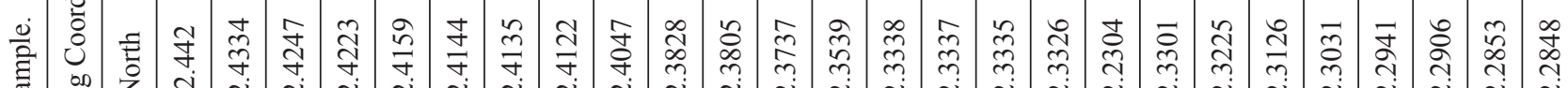
矛

产言

祃

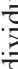

\begin{tabular}{|c|c|c|c|c|c|c|c|c|c|c|c|c|c|c|c|c|c|c|c|c|c|c|c|c|c|}
\hline & $\begin{array}{l}\overrightarrow{\tilde{a}} \\
\stackrel{\Delta}{u}\end{array}$ & 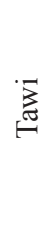 & 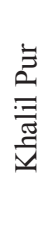 & $\stackrel{\Xi}{\Xi}$ & $\begin{array}{l}\frac{\tilde{\pi}}{\pi} \\
\sum_{\pi}^{\pi}\end{array}$ & 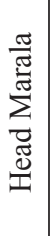 & $\begin{array}{l}\frac{\pi}{\pi} \\
\frac{\pi}{\pi} \\
\frac{\pi}{\Sigma}\end{array}$ & 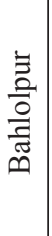 & 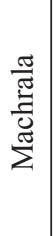 & 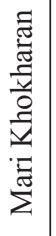 & $\begin{array}{l}\frac{\pi}{\tilde{W}} \\
0 \\
0 \\
\text { U }\end{array}$ & 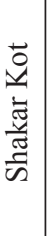 & 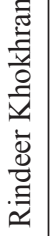 & 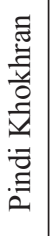 & 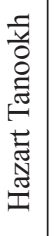 & $\begin{array}{l}\overline{8} \\
\overline{0} \\
\overline{0}\end{array}$ & 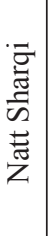 & $\begin{array}{l}\frac{\pi}{\pi} \\
\frac{\tilde{n}}{2} \\
\text { J }\end{array}$ & $\frac{0}{\frac{0}{0}}$ & 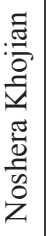 & 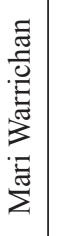 & 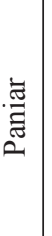 & 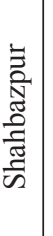 & 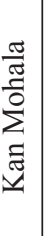 & $\begin{array}{l}\overrightarrow{\bar{\Xi}} \\
0 \\
0\end{array}$ \\
\hline & 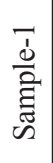 & 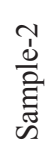 & 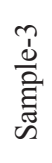 & 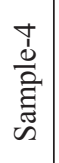 & 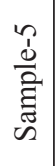 & $\begin{array}{l}\mathbf{l} \\
\stackrel{d}{0} \\
\text { : }\end{array}$ & 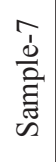 & 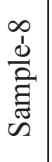 & 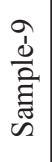 & $\begin{array}{l}\frac{0}{d} \\
\frac{\dot{d}}{a} \\
\stackrel{a}{a}\end{array}$ & $\begin{array}{l}\overline{\vec{d}} \\
\frac{\grave{g}}{\vec{g}}\end{array}$ & 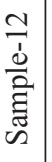 & 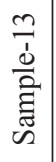 & $\begin{array}{l}\frac{\Delta}{\dot{d}} \\
\frac{\overrightarrow{0}}{\vec{a}}\end{array}$ & $\begin{array}{l}\frac{n}{\dot{d}} \\
\frac{0}{a} \\
\frac{a}{a}\end{array}$ & 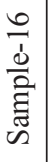 & 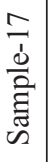 & $\frac{\infty}{\frac{\infty}{0}}$ & $\begin{array}{l}\frac{a}{d} \\
\frac{\partial}{\vec{a}}\end{array}$ & $\begin{array}{l}\stackrel{?}{1} \\
\stackrel{0}{0} \\
\stackrel{a}{a}\end{array}$ & $\begin{array}{l}\overrightarrow{\hat{v}} \\
\stackrel{0}{\overrightarrow{2}} \\
\vec{z}\end{array}$ & 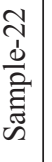 & 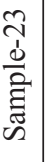 & $\underset{j}{\mathbb{j}}$ & 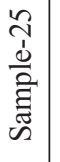 \\
\hline
\end{tabular}




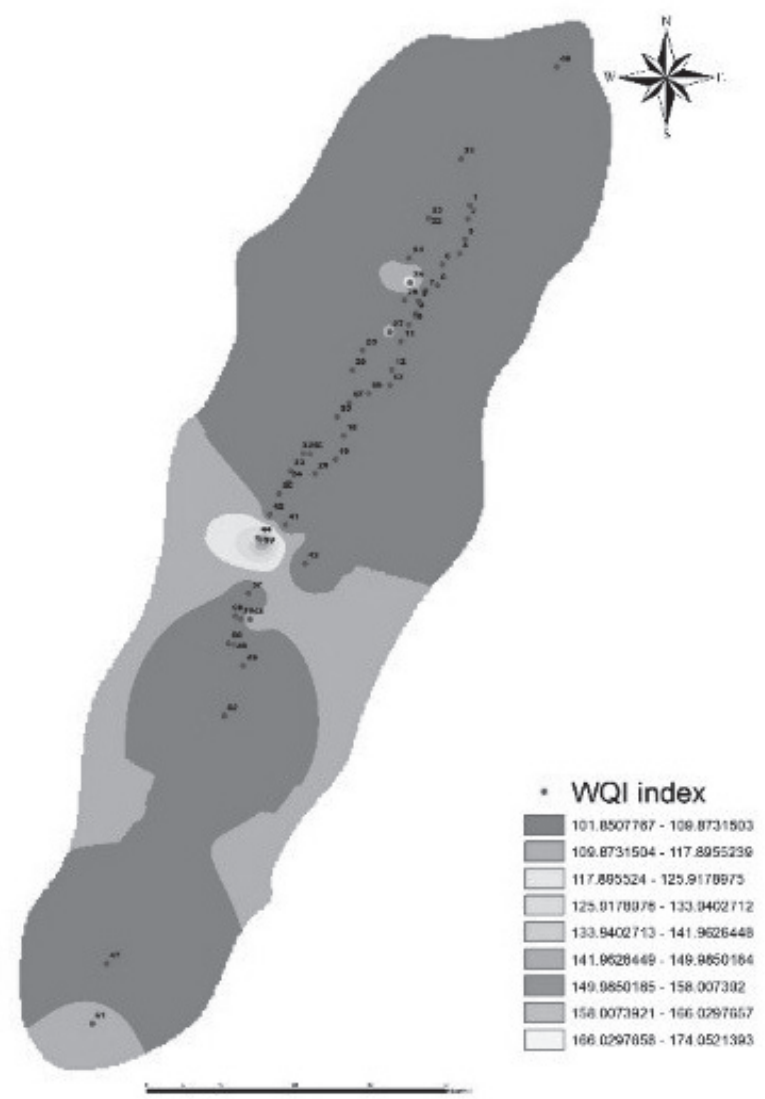

Fig. 5. The thematic layer map of WQI for River Chenab.

\section{Assessment of Water Quality Index}

Water quality index was used to understand the overall surface water quality. The values of water quality index in all samples remained from 101.8 to 123.4 with a mean value of 107.89 indicating poor water quality (Table 3 and Fig. 5). Presented values of WQI indicated that water is not fit for drinking purposes. All contaminated surface water areas are located near the sewage drains that deplete the surface water quality through direct discharge and seepage. Xiao et al. [16] was also conducted a similar study and found $3 \%$ of collected samples were not suitable for drinking purpose. WQI of ground water of Province Baluchistan indicated that all water samples were contaminated and not suitable for drinking purposes due to the presence of numerous heavy metals and differences in some physicochemical parameters which are mainly due to human activities [35]. Only 3.1\% surface water samples had excellent WQI in 2010 that further contaminated after few years of human activities [76]. Groundwater of District Faisalabad is also being deteriorated by adjacent sewerage wastewater drains and industrial discharge and showed a significant rise in drinking water pollution beyond the limits provided by WHO [74]. WQI was found 75 in 2008 and it was raised more than 100 in the year of 2009 in Iraq which depicted that the precautionary measures taken by the government were not sufficient to develop the quality of water [77].

\section{Health Risk Assessment}

For the health risk assessment in adults and children, hazard quotient (HQ) and average daily dose (ADD) indices were calculated of drinking and surface water of river Chenab. These indices were also measured by some other scholars like Mahfooz et al. [49], Titilawo et al. [4] and Kamunda et al, [78]. Table 4 presents the average value of CAR for carcinogenic and HQ and ADD for non-carcinogenic risk assessment in surface water of river Chenab. The HQ values of As in surface water was $(0.643317498,0.972696057)$ and of $\mathrm{Cr}$ was $(0.213834933,3.371749231)$ for adults and children respectively. A study was led by Mahfooz et al. [49] that indicated the Cr values very close to threshold limit $(\mathrm{HQ}>1)$ both in children and adult in Faisalabad. The HQ order of surface water samples were given as $\mathrm{Ni}>\mathrm{Pb}, \mathrm{As}>\mathrm{Cr}$ and $\mathrm{Cu}$ in adult and $\mathrm{Pb}>\mathrm{Ni}, \mathrm{Cr}>\mathrm{As}, \mathrm{Cu}$ in children. The HQ values of $\mathrm{Cu}, \mathrm{Co}, \mathrm{Pb}$ and $\mathrm{Cd}$ were much greater than their acceptable limits in children in groundwater of Chitral, Pakistan [48]. The results of present study are parallel to the findings of Kavcar et al. [79]. Muhammad et al. [18] determined that the HQ indices for heavy metals reflected no hazard to native residents as compared to the previous researches but the HQ indices of $\mathrm{Pb}, \mathrm{Zn}, \mathrm{Ni}, \mathrm{Cd}$ and $\mathrm{Cu}$ indicated to be greater than what Lim et al. [80] studied in surface water and what Kavcar et al. [79] studied in drinking water. Xiao et al. [16] indicated that in case of As $\mathrm{HQ}>1$ particularly among children were greater than adults, showing that in alike surrounding, children are more vulnerable than that of adults. The occurrence of As in drinking water for long period of time could be the reason of cancer and diabetes, skin abrasions, neuropathy, hypertension, etc. Arid and semi-arid climatic conditions and coal mining can also cause As contamination [81, 82]. Non-carcinogenic hazard index of river water which showed no impact in the residents might be increased by heavy metals exposure [4]. Risk is predicted to initiate in the body of human beings if cancer risk value increased than $1 \times 10-4$ [83]. In the present study, the values for cancer risk in drinking water was higher for As (2.89493E-04) in adults and in children (3.75183E-05), the value of $\mathrm{Cr}$ was (2.6301697E-02) in adults while (3.554787E-02) in children (Table 4). All the parameters of As, Cr and Ni pose a major threat of cancer in children. In a similar study of Rehman et al. [48] determined the values of $\mathrm{Cd}, \mathrm{Cr}$, $\mathrm{Ni}$ and $\mathrm{Co}$ in adults and children above permissible limit of carcinogenicity. Exposure to heavy metal toxicity in drinking water can be the result of carcinogenic risk which can be life threatening for the native residents [18].

The results of the current study show that water quality was poor for drinking purpose. This is related to the health risk assessment. Poor drinking water quality poses major health issues in children and adults which can cause cancer, particularly in the occurrence of heavy metals. The main source of pollution in river 


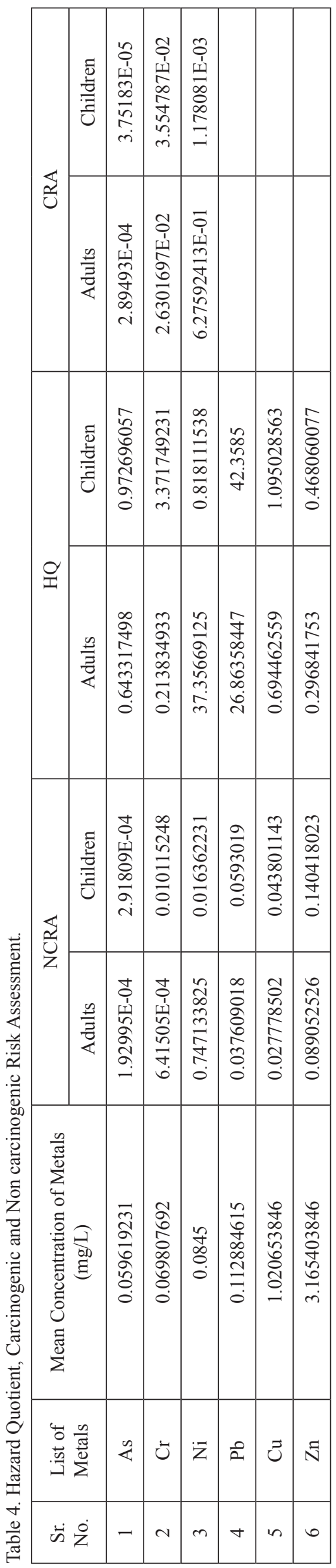

water is industrial and domestic discharge without treatment. The use of water for irrigation and drinking purposes, cause different diseases in local community which include lung cancer, hypertension, stomach cancer, anemia, gastroenteritis, intellectual disabilities and cardiac arrest in the surroundings of agricultural, mining and industrial activities [48].

\section{Conclusion}

The current study comprehensively reflected the water contamination and related health risks in the water of Chenab river of Pakistan. Most of the parameters which includes biological, physicochemical and heavy metals (total dissolved solids, chloride, nickel, As, $\mathrm{Cr}$ and bacteriological contamination) exceeded the WHO and NEQs-Pak allowable limits. The result of water quality index indicated water is of poor quality in major sampling locations where large number of industries occurred and contaminate water quality and leads to the onset of many health issues. For As, carcinogenic and non-carcinogenic risk was detected among adults and children, in surface water bodies. The values of CRA and HQ were greater than the permissible limit which exist in adults and children. The domestic and industrial discharge greatly effect on surface water quality and generated an alarming situation for the health of local residents and surrounding ecosystem. Proper monitoring and Protective measures are would be necessary to remove the health risk in the native inhabitants. The present study will be helpful for policy makers and local government bodies for the establishment and implementation of well-defined monitoring system and reduce health related issues in local area. This research is further recommended the evaluation of persistent organic pollutants in this agricultural and industrial zone particularly pesticides which leads to many health issues.

\section{Acknowledgement}

The present research work is the part of $\mathrm{PhD}$ research work of Ms. Ayesha Siddiqua. The authors are thankful to the Punjab University, Lahore, Pakistan for support during the research work and analysis.

\section{Conflict of Interest}

The authors declare no conflict of interest.

\section{References}

1. SUDARSHAN P., MAHESH M.K., RAMACHANDRA T.V. Assessment of seasonal variation in water quality and water quality index (WQI) of Hebbal Lake, Bangalore, India. Environment and Ecology, 37 (1B), 309, 2019. 
2. LI J., LI F., LIU Q., ZHANG Y. Trace metal in surface water and groundwater and its transfer in a Yellow River alluvial fan: Evidence from isotopes and hydrochemistry. Science of the Total Environment, 472, 979, 2014.

3. GHORADE I.B., LAMTURE S.V., PATIL S.S. Assessment of heavy metal content in Godavari river water. International Journal of Research, Applied Nature and Social Sciences, 2 (6), 23, 2014.

4. TITILAWO Y., ADENIJI A., ADENIYI M., OKOH A. Determination of levels of some metal contaminants in the freshwater environments of Osun State, Southwest Nigeria: a risk assessment approach to predict health threat. Chemosphere, 211, 834, 2018.

5. VESALI NASEH M., NOORI R., BERNDTSSON R., ADAMOWSKI J., SADATIPOUR E. Groundwater pollution sources apportionment in the Ghaen Plain, Iran. International journal of environmental research and public health, 15 (1), 172, 2018.

6. JIA H., YAO H., SHAW L.Y. Advances in LID BMPs research and practice for urban runoff control in China. Frontiers of Environmental Science \& Engineering, 7 (5), 709, 2013.

7. GRIMM N.B., FAETH S.H., GOLUBIEWSKI N.E., REDMAN C.L., WU J., BAI X., BRIGGS J.M. Global change and the ecology of cities. Science, 319 (5864), 756, 2008.

8. NAWAB J., KHAN S., XIAOPING W., RAHMAN A., ALI H., QAMAR Z., KHAN, A. Spatial distribution of toxic metals in drinking water sources and their associated health risk in district buner, Northern Pakistan. Human and Ecological Risk Assessment: An International Journal, 24 (3), 615, 2018.

9. ABBAS Q., YOUSAF B., LIU G., ZIA-UR-REHMAN M., ALI M. U., MUNIR M.A.M., HUSSAIN S.A. Evaluating the health risks of potentially toxic elements through wheat consumption in multi-industrial metropolis of Faisalabad, Pakistan. Environmental Science and Pollution Research, 24 (34), 26646, 2017.

10. YOUSAF B., LIU G., WANG R., IMTIAZ M., RIZWAN M.S., ZIA-UR-REHMAN M., SI Y. The importance of evaluating metal exposure and predicting human health risks in urban-periurban environments influenced by emerging industry. Chemosphere, 150, 79, 2016.

11. MUKATE S., PANASKAR D., WAGH V., MULEY A., JANGAM C., PAWAR R. Impact of anthropogenic inputs on water quality in Chincholi industrial area of Solapur, Maharashtra, India. Groundwater for Sustainable Development, 7, 359, 2018.

12. QADIR A., MALIK R.N., HUSAIN S.Z. Spatio-temporal variations in water quality of Nullah Aik-tributary of the river Chenab, Pakistan. Environmental monitoring and assessment, 140 (1-3), 43, 2008

13. DONG Z., QIN D., QIN X., CUI J., KANG S. Changes in precipitating snow chemistry with seasonality in the remote Laohugou glacier basin, western Qilian Mountains. Environmental Science and Pollution Research, 24 (12), 11404, 2017.

14. ZENG X., LIU Y., YOU S., ZENG G., TAN X., HU X., LI F. Spatial distribution, health risk assessment and statistical source identification of the trace elements in surface water from the Xiangjiang River, China. Environmental Science and Pollution Research, 22 (12), 9400, 2015.

15. CHOWDHURY S., MAZUMDER M.J., AL-ATTAS O., HUSAIN T. Heavy metals in drinking water: occurrences, implications, and future needs in developing countries. Science of the total Environment, 569, 476, 2016.
16. XIAO J., WANG L., DENG L., JIN Z. Characteristics, sources, water quality and health risk assessment of trace elements in river water and well water in the Chinese Loess Plateau. Science of the Total Environment, 650, 2004, 2019.

17. KHAN K., LU Y., KHAN H., ZAKIR S., KHAN S., KHAN A.A., WANG T. Health risks associated with heavy metals in the drinking water of Swat, northern Pakistan. Journal of Environmental Sciences, 25 (10), 2003, 2013

18. MUHAMMAD S., SHAH M.T., KHAN S. Health risk assessment of heavy metals and their source apportionment in drinking water of Kohistan region, northern Pakistan. Microchemical journal, 98 (2), 334, 2011.

19. World Health Organization. Investing to overcome the global impact of neglected tropical diseases: third WHO report on neglected tropical diseases 2015 (Vol. 3). World Health Organization. 2015.

20. ISHAQUE W., SHAIKH S. Water and energy security for Pakistan a retrospective analysis. Grassroots, 51 (1). 2017.

21. KHAN S., SHAHNAZ M., JEHAN N., REHMAN S., SHAH M.T., DIN I. Drinking water quality and human health risk in Charsadda district, Pakistan. Journal of cleaner production, 60, 93, 2013.

22. HUSSAIN Y., ULLAH S.F., AKHTER G., ASLAM A.Q. Groundwater quality evaluation by electrical resistivity method for optimized tubewell site selection in an agostressed Thal Doab Aquifer in Pakistan. Modeling Earth Systems and Environment, 3 (1), 15, 2017.

23. KHAIR S.M., MUSHTAQ S., CULAS R.J., HAFEEZ M. Groundwater markets under the water scarcity and declining watertable conditions: The upland Balochistan Region of Pakistan. Agricultural Systems, 107, 21, 2012.

24. KHAN A., HUSAIN V., BAKHTIARI A.E. Groundwater arsenic contamination in semi-urban areas of Tando Muhammad Khan District: a case study from deltaic flood plain of Sindh, Pakistan. Sustainable Environment, 2 (2), 171, 2017.

25. FAO. FAO Statistical Yearbook: World Food and Agriculture. FAO. 2013.

26. FAHAD S., WANG J. Farmers' risk perception, vulnerability, and adaptation to climate change in rural Pakistan. Land use policy, 79, 301, 2018.

27. TANG J., FOLMER H., XUE, J. Estimation of awareness and perception of water scarcity among farmers in the Guanzhong Plain, China, by means of a structural equation model. Journal of environmental management, 126, 55, 2013.

28. YOUSAF B., LIU G., WANG R., IMTIAZ M., ZIA-URREHMAN M., MUNIR M. A.M., NIU Z. Bioavailability evaluation, uptake of heavy metals and potential health risks via dietary exposure in urban-industrial areas. Environmental Science and Pollution Research, 23 (22), 22443, 2016.

29. LI P., TIAN R., XUE C., WU J. Progress, opportunities, and key fields for groundwater quality research under the impacts of human activities in China with a special focus on western China. Environmental Science and Pollution Research, 24 (15), 13224,. 2017.

30. CHABUKDHARA M., GUPTA S.K., KOTECHA Y., NEMA A.K. Groundwater quality in Ghaziabad district, Uttar Pradesh, India: Multivariate and health risk assessment. Chemosphere, 179, 167, 2017.

31. AZIZULLAH A., KHATTAK M.N.K., RICHTER P., HÄDER D.P. Water pollution in Pakistan and its impact 
on public health - a review. Environment international, 37 (2), 479, 2011.

32. KHAN S., SHAHNAZ M., JEHAN N., REHMAN S., SHAH M.T., DIN I. Drinking water quality and human health risk in Charsadda district, Pakistan. Journal of cleaner production, 60, 93, 2013.

33. KHAIR S.M., MUSHTAQ S., REARDON-SMITH K. Groundwater Governance in a Water-Starved Country: Public Policy, Farmers' Perceptions, and Drivers of Tubewell Adoption in Balochistan, Pakistan. Groundwater, 53 (4), 626, 2015.

34. VAN STEENBERGEN F., KAISARANI A.B., KHAN N.U., GOHAR M.S. A case of groundwater depletion in Balochistan, Pakistan: Enter into the void. Journal of Hydrology: Regional Studies, 4, 36, 2015.

35. KHALID S. An assessment of groundwater quality for irrigation and drinking purposes around brick kilns in three districts of Balochistan province, Pakistan, through water quality index and multivariate statistical approaches. Journal of Geochemical Exploration, 197, 14, 2019.

36. DAUD M.K., NAFEES M., ALI S., RIZWAN M., BAJWA R.A., SHAKOOR M.B., MALOOK, I. Drinking water quality status and contamination in Pakistan. BioMed research international, 2017.

37. KHALID S., MURTAZA B., SHAHEEN I., AHMAD I., ULLAH M.I., ABBAS T., IMRAN M. Assessment and public perception of drinking water quality and safety in district Vehari, Punjab, Pakistan. Journal of cleaner production, 181, 224, 2018.

38. SHAKOOR A., ZAHID M.K., FARID H.U., SULTAN M., AFTAB A.K., AHMAD I., AZMAT M. Groundwater vulnerability mapping in Faisalabad district using GIS based drastic model. In MATEC web of conferences. 246, 01001, EDP Sciences. 2018.

39. WEN X., YANG Q., YAN Z., DENG Q. Determination of cadmium and copper in water and food samples by dispersive liquid-liquid microextraction combined with UV-vis spectrophotometry. Microchemical Journal, 97 (2), 249, 2011.

40. AVINO P., CAPANNESI G., ROSADA A. Ultra-trace nutritional and toxicological elements in Rome and Florence drinking waters determined by Instrumental Neutron Activation Analysis. Microchemical Journal, 97 (2), 144, 2011.

41. ESCUDERO L.A., MARTINEZ L.D., SALONIA, J.A., GASQUEZ J.A. Determination of Zn (II) in natural waters by ICP-OES with on-line preconcentration using a simple solid phase extraction system. Microchemical Journal, 95 (2), 164, 2010.

42. FOX D.R. Probability weighted indices for improved ecosystem report card scoring. Environmetrics, 25 (5), 351, 2014.

43. ADAMS V.D. Water and wastewater examination manual. Routledge.

44. PANSAMUT S., WATTAYAKORN G. (2009). Determination of arsenic in water and sediment from Thailand using inductively coupled plasma mass spectrometry. Journal of Environmental research and development, 3 (3), 2017.

45. AHMAD S.S., BASHIR H. Investigating Satellite Based Navigation Approach in Soil Loss Predication - Case Study of Soan Watershed, Pakistan. In EuroMediterranean Conference for Environmental Integration. 1811-1812. Springer, Cham. 2017.

46. TYAGI S., SHARMA B., SINGH P., DOBHAL R. Water quality assessment in terms of water quality index. American Journal of Water Resources, 1 (3), 34, 2013.

47. Agency for Toxic Substances, Disease Registry (ASTDR) 2007.

48. UR REHMAN I., ISHAQ M., ALI L., KHAN S., AHMAD I., DIN I.U., ULLAH H. Enrichment, spatial distribution of potential ecological and human health risk assessment via toxic metals in soil and surface water ingestion in the vicinity of Sewakht mines, district Chitral, Northern Pakistan. Ecotoxicology and environmental safety, 154, 127, 2018.

49. MAHFOOZ Y., YASAR A., SOHAIL M.T., TABINDA A.B., RASHEED R., IRSHAD S., YOUSAF B. Investigating the drinking and surface water quality and associated health risks in a semi-arid multi-industrial metropolis (Faisalabad), Pakistan. Environmental Science and Pollution Research, 26 (20), 20853, 2019.

50. EPA U. Guidelines for Water Reuse, US Environmental Protection Agency. EPA/625/R-04/108. 2004.

51. USEPA Child-specific exposure scenarios examples. EPA/600/R-14/217F National Center for Environmental Assessment, Office of Research and Development, U.S. 2014.

52. United State Environmental Protection Agency (USEPA) Guidelines for exposure assessment Fed Regist 57 (104), 22888, 1992.

53. WEI H., LE Z., SHUXIAN L., DAN W., XIAOJUN L., LAN J., XIPING M. Health Risk Assessment of Heavy Metals and Polycyclic Aromatic Hydrocarbons In Soil At Coke Oven Gas Plants. Environmental Engineering and Management Journal (EEMJ), 14 (2), 2015.

54. AKTAR M.W., PARAMASIVAM M., GANGULY M., PURKAIT S., SENGUPTA D. Assessment and occurrence of various heavy metals in surface water of Ganga river around Kolkata: a study for toxicity and ecological impact. Environmental monitoring and assessment, 160 (1-4), 207, 2010.

55. RIM-RUKEH A., IKHIFA O.G., OKOKOYO A.P. Effects of agricultural activities on the water quality of Orogodo River, Agbor Nigeria. Journal of applied sciences research, 2 (5), 256, 2006.

56. PHIRI O., MUMBA P., MOYO B.H.Z., KADEWA W. Assessment of the impact of industrial effluents on water quality of receiving rivers in urban areas of Malawi. International Journal of Environmental Science \& Technology, 2 (3), 237, 2005.

57. MAHANANDA M.R., MOHANTY B.P., BEHERA N.R. Physico-chemical analysis of surface and ground water of Bargarh District, Orissa, India. International journal of research and reviews in applied sciences, 2 (3), 284, 2010.

58. PATIL P.N., SAWANT D.V., DESHMUKH R.N. Physicochemical parameters for testing of water - A review. International Journal of Environmental Sciences, 3 (3), 1194, 2012.

59. KATTAN Z. Using hydrochemistry and environmental isotopes in the assessment of groundwater quality in the Euphrates alluvial aquifer, Syria. Environmental earth sciences, 77 (2), 45, 2018.

60. MUMTAZ M.W., ADNAN A., MUKHTAR H., NAWAZ K., RAZA A., AHMAD Z. Estimation of bacteriological levels in surface water samples to evaluate their contamination profile. Environmental monitoring and assessment, 172 (1-4), 581, 2011.

61. BHUTTA M.N., RAMZAN M., HAFEEZ C.A. Ground water quality and availability in Pakistan: Pakistan 
Council for Research in Water Resources (PCRWR). Islamabad, Pakistan. 2002.

62. KHAN K., LU Y., SAEED M.A., BILAL H., SHER H., KHAN H., LI Q. Prevalent fecal contamination in drinking water resources and potential health risks in Swat, Pakistan. Journal of Environmental Sciences, 72, 1, 2018.

63. NOREEN M., SHAHID M., IQBAL M., NISAR J. Measurement of cytotoxicity and heavy metal load in drains water receiving textile effluents and drinking water in vicinity of drains. Measurement, 109, 88, 2017.

64. RAFIQ M., SHAHID M., SHAMSHAD S., KHALID S., NIAZI N.K., ABBAS G., MURTAZA B. A comparative study to evaluate efficiency of EDTA and calcium in alleviating arsenic toxicity to germinating and young Vicia faba L. seedlings. Journal of Soils and Sediments, 18 (6), 2271, 2018.

65. SHAHID M., NIAZI N.K., DUMAT C., NAIDU R., KHALID S., RAHMAN M.M., BIBI I. A meta-analysis of the distribution, sources and health risks of arseniccontaminated groundwater in Pakistan. Environmental pollution, 242, 307, 2018.

66. SHAKOOR M.B., NIAZI N.K., BIBI I., MURTAZA G., KUNHIKRISHNAN A., SESHADRI B., ABID M. Remediation of arsenic-contaminated water using agricultural wastes as biosorbents. Critical Reviews in Environmental Science and Technology, 46 (5), 467, 2016.

67. MEHMOOD T., BIBI I., SHAHID M., NIAZI N.K., MURTAZA B., WANG H., MURTAZA G. Effect of compost addition on arsenic uptake, morphological and physiological attributes of maize plants grown in contrasting soils. Journal of Geochemical Exploration, 178, 83, 2017.

68. ABBAS G., MURTAZA B., BIBI I., SHAHID M., NIAZI N.K., KHAN M.I., HUSSAIN M. Arsenic uptake, toxicity, detoxification, and speciation in plants: physiological, biochemical, and molecular aspects. International journal of environmental research and public health, 15 (1), 59, 2018.

69. BRAHMAN K.D., KAZI T.G., AFRIDI H.I., NASEEM S., ARAIN S.S., ULLAH N. Evaluation of high levels of fluoride, arsenic species and other physicochemical parameters in underground water of two sub districts of Tharparkar, Pakistan: a multivariate study. Water research, 47 (3), 1005, 2013

70. SINGH A.K. Chemistry of arsenic in groundwater of Ganges-Brahmaputra river basin. Current Science, 599, 2006.

71. BAIG J.A., KAZI T.G., SHAH A.Q., KANDHRO G.A., AFRIDI H.I., ARAIN M.B., JALBANI N. Speciation and evaluation of Arsenic in surface water and groundwater samples: A multivariate case study. Ecotoxicology and environmental safety, 73 (5), 914, 2010.
72. ALI J., KAZI T.G., TUZEN M., ULLAH N. Evaluation of mercury and physicochemical parameters in different depths of aquifer water of Thar coalfield, Pakistan. Environmental Science and Pollution Research, 24 (21), 17731, 2017.

73. KAUSAR F., QADIR A., AHMAD S.R., BAQAR M. Evaluation of surface water quality on spatiotemporal gradient using multivariate statistical techniques: a case study of River Chenab, Pakistan. Polish Journal of Environmental Studies, 28 (4), 2019.

74. YAMIN M., NASIR A., SULTAN M., ISMAIL W.I.W., SHAMSHIRI R., AKBAR F.N. Impact of sewage and industrial effluents on water quality in Faisalabad, Pakistan. Advances in Environmental Biology, 9 (18), 53, 2015.

75. KUMARI B., KUMAR V., SINHA A.K., AHSAN J., GHOSH A.K., WANG H., DEBOECK G. Toxicology of arsenic in fish and aquatic systems. Environmental chemistry letters, 15 (1), 43, 2017.

76. AL-MUTAIRI N., ABAHUSSAIN A., EL-BATTAY A. Application of water quality index to assess the environmental quality of Kuwait Bay. In International Conference on Advances in Agriculture, Biological \& Environmental Sciences (AABES-2014) 15, 2014.

77. ABDUL HAMEED M JAWAD A., HAIDER S.A., BAHRAM K.M. Application of water quality index for assessment of Dokan lake ecosystem, Kurdistan region, Iraq. journal of water resource and protection, 2010.

78. KAMUNDA C., MATHUTHU M., MADHUKU M. Health risk assessment of heavy metals in soils from Witwatersrand gold mining basin, South Africa. International Journal of Environmental Research and Public Health, 13 (7), 663, 2016.

79. KAVCAR P., SOFUOGLU A., SOFUOGLU S.C.A health risk assessment for exposure to trace metals via drinking water ingestion pathway. International journal of hygiene and environmental health, 212 (2), 216, 2009

80. LIM H.S., LEE J.S., CHON H.T., SAGER M. Heavy metal contamination and health risk assessment in the vicinity of the abandoned Songcheon Au-Ag mine in Korea. Journal of Geochemical Exploration, 96 (2-3), 223, 2008.

81. XIAO J., ZHANG F., JIN Z. Spatial characteristics and controlling factors of chemical weathering of loess in the dry season in the middle Loess Plateau, China. Hydrological Processes, 30 (25), 4855, 2016.

82. HE J., CHARLET L. A review of arsenic presence in China drinking water. Journal of hydrology, 492, 79, 2013.

83. HU X., ZHANG Y., DING Z., WANG T., LIAN H., SUN Y., WU J. Bioaccessibility and health risk of arsenic and heavy metals ( $\mathrm{Cd}, \mathrm{Co}, \mathrm{Cr}, \mathrm{Cu}, \mathrm{Ni}, \mathrm{Pb}, \mathrm{Zn}$ and $\mathrm{Mn}$ ) in TSP and PM2.5 in Nanjing, China. Atmospheric environment, 57, 146, 2012 . 